\title{
24. PRELIMINARY PALYNOLOGICAL RESULTS: SITE 361, LEG 40, DEEP SEA DRILLING PROJECT
}

\author{
Ian R. McLachlan and Elizabeth Pieterse, \\ Southern Oil Exploration Corporation (Pty) Ltd. (SOEKOR), Johannesburg, South Africa
}

\begin{abstract}
Site 361 lies about 180 miles west-southwest of Cape Town. A single hole drilled to 1314 meters (subbottom) intersected a nearly continuous sequence of sediments ranging in age from Aptian to Eocene. Palynological studies were undertaken on 48 samples from the Cretaceous interval (Cores 12 to 48 ) and palynomorphs were recovered from nearly all the cores treated. The age indications generally support those based on foraminifers and coccoliths. Further information is provided on depositional environments, sediment provenance, and climate. The sapropelic lower lithological interval was probably deposited in a near-shore situation. The climate is interpreted as having been dry and the organic material was derived from a Classopollis-dominated local plant community. A benthic microfauna did exist, but the calcareous shells were mostly destroyed during early burial by acid interstitial fluids associated with the carbonaceous sediment. A diverse assemblage of dinoflagellate cysts with many cosmopolitan species indicates a free circulation of the surface water and a connection with the oceanic seas. The basin was probably silled, with restricted circulation of bottom water. The phytoplankton ratio increases markedly in the Upper Cretaceous as a result of the diminished supply of terrigenous spores and pollen, but species diversities remain constant. Bottom waters were generally well oxygenated. There is a suggestion of shallowing or a closer sediment source at three intervals within the Upper Cretaceous, where the delicate nature of the cuticular material suggests minimal transport of the plant debris. The climate at this time was probably wet and floras were dominated by ferns and angiosperms. Striated bisaccate pollen characteristic of the Permian and Triassic is persistently present in the Upper Cretaceous and points to a provenance in the southwestern Cape in South Africa. The sapropelic basal lithological unit has the appearance of a good petroleum source rock and is interpreted to be near the upper limit of thermal maturity necessary for the generation of hydrocarbons.
\end{abstract}

\section{INTRODUCTION}

This study was carried out as part of a shore-based palynological investigation. Samples were provided by Dr. W. Siesser of the University of Cape Town from all Cretaceous cores except Cores 26, 29, 38, 44, and 49. These were later supplied by Professor Bolli. Sample details are shown in Table 1 and the position of Site 361 is shown in Figure 1. Cores 12-27 are from lithologic Unit 6 of Site 361 (Chapter 2, this volume) and Cores 28-49 are from Unit 7.

Before palynological processing the samples were soaked in water to disaggregate them and washed onto a 150 mesh screen to remove any megaspores or microfaunal shells which might have been present. The minus 150 mesh sludge was then subjected to standard palynological processing. Slides were prepared of both unoxidized and stained oxidized organic residues.

Because the time available for study initially was short, this report was first prepared without taxonomic notes or photographic illustration, concentrating on providing information relevant to the geology of Site 361. To this end, comments were made where possible on the ideas presented by the shipboard party in the Leg 40 Hole Summary Book-material subsequently incorporated into Chapters 1 and 2 of this volume, and the initial report of the shipboard party. An extension of time allowed the inclusion, as an addendum, of taxonomic and descriptive notes and illustrations of the spores and pollen only. The dinoflagellates and acritarchs are described and illustrated by Davey (this volume).

The most important results and conclusions are displayed in Figure 2.

\section{PALYNOLOGICAL RESULTS}

\section{Spores and Pollen}

The main results are shown in Table 1, and in Figures 2 and 3. Miospore preservation is generally good, 
TABLE 1

Details of Samples Processed, Site 361, Leg 40

\begin{tabular}{|c|c|c|c|c|c|c|}
\hline $\begin{array}{c}\text { SOEKOR } \\
\text { Palynology } \\
\text { Sample } \\
\text { Number }\end{array}$ & \multicolumn{2}{|c|}{$\begin{array}{c}\text { Sample } \\
\text { (Interval in cm) }\end{array}$} & Miospores & $\begin{array}{c}\text { Phyto- } \\
\text { plankton }\end{array}$ & $\begin{array}{l}\text { Micro- } \\
\text { foramin- } \\
\text { ifera }\end{array}$ & $\begin{array}{c}\text { Mega- } \\
\text { spores } \\
\text { Forams }\end{array}$ \\
\hline 4977 & $12-3,9$ & $10-92$ & - & - & - & $\mathrm{F}$ \\
\hline 4978 & $13-1,1$ & $23-125$ & ++ & +++ & + & M \\
\hline 4979 & $14-2,5$ & $5-57$ & - & - & - & \\
\hline 4980 & $15-2,1$ & $9-21$ & - & - & - & \\
\hline 4981 & $15, \mathrm{CC}$ & & - & - & - & $\mathrm{F}$ \\
\hline 4982 & $16-1,3$ & $3-35$ & + & - & - & \\
\hline 4983 & $17-2,5$ & 1.33 & ++ & ++ & - & \\
\hline 4984 & $18-2,1$ & $40-141$ & ++ & + & + & \\
\hline 4985 & $19-2,1$ & $43-145$ & ++ & ++ & + & \\
\hline 4986 & $19-4,9$ & $1-92$ & + & ++ & - & \\
\hline 4987 & $20-2,1$ & $44-146$ & H+H & ++ & + & \\
\hline 4988 & $21-2,1$ & $31-133$ & +++ & ++ & + & \\
\hline 4989 & $22-2,9$ & $2-94$ & +++ & +++ & + & \\
\hline 4990 & $23-2,6$ & $1-64$ & ++ & +++ & + & \\
\hline 4991 & $24-2,9$ & 6-98 & ++ & +++ & & \\
\hline 4992 & $25-3,9$ & $4-97$ & - & - & - & \\
\hline- & $26-2,2$ & $6-28$ & ) & & & \\
\hline - & $26-3,5$ & $9-61$ & j & & & \\
\hline - & $26-4,5$ & $8-60$ & - & - & - & \\
\hline - & $26-5,5$ & $8-60$ & ) & & & \\
\hline- & $26-6,6$ & $0-62$ & j & & & \\
\hline 4993 & $27-2,1$ & $19-121$ & +++ & t+ & + & \\
\hline 4994 & $28-4,6$ & $1-63$ & + & - & - & \\
\hline 4995 & $28-6,1$ & $15-117$ & ++ & ++ & + & \\
\hline- & $29-3,4$ & $8-50$ & ++ & ++ & & \\
\hline 4996 & $30-1,5$ & $5-57$ & + & - & - & \\
\hline 4997 & $31 \cdot 4,1$ & $29-131$ & ++ & ++ & - & F \\
\hline 4998 & $32-2$, & $17-119$ & ++ & +++ & + & $\mathrm{F}$ \\
\hline 4999 & $33-2,2$ & $7-28$ & + & - & - & \\
\hline 5000 & $33-3,1$ & $17-118$ & ++ & ++ & + & \\
\hline 5001 & $34-2,6$ & $0-62$ & ++ & ++ & + & \\
\hline 5002 & $35-2,1$ & $30-132$ & ++ & + & + & \\
\hline 5003 & $35 \cdot 3,5$ & $0-52$ & + & + & - & M \\
\hline 5004 & $36-1,1$ & 03-105 & + & + & - & M \\
\hline 5005 & $36-2,1$ & $36-138$ & ++ & + & + & \\
\hline 5006 & $36-3,7$ & $7-79$ & ++ & + & - & M \\
\hline 5007 & $37-2,1$ & $29-131$ & ++ & + & + & \\
\hline- & $38-2,3$ & $8-40$ & ++ & ++ & & \\
\hline 5008 & $39-1,1$ & $17-119$ & + & - & - & \\
\hline 5009 & $39-2,4$ & $6-48$ & + & - & - & \\
\hline 5010 & $40-2,8$ & $77-89$ & + & + & - & \\
\hline 5011 & $40-3,9$ & $9-101$ & ++ & ++ & + & \\
\hline 5012 & $41-1,9$ & $0-92$ & ++ & + & - & \\
\hline 5013 & $41-2,8$ & $6-88$ & ++ & - & - & \\
\hline 5014 & $41-3,5$ & $3-55$ & + & ++ & + & \\
\hline 5015 & $42-1,7$ & $5-77$ & ++ & - & - & \\
\hline 5016 & $43-1$, & $28-130$ & ++ & - & - & \\
\hline 5017 & $43-2,1$ & $16-118$ & ++ & ++ & + & \\
\hline 5018 & $43-3,1$ & $2-13$ & ++ & ++ & + & \\
\hline- & $44-2$, & $111-113$ & ++ & ++ & & \\
\hline 5019 & $45-1$ & $34-136$ & + & + & - & M \\
\hline 5020 & $45-2$, & $3-95$ & ++ & - & + & \\
\hline 5021 & $45-3$, & $04-105$ & + & - & - & \\
\hline 5022 & $46-2,1$ & $24-125$ & + & + & + & \\
\hline 5023 & $47-1$ & $28-130$ & +++ & +++ & + & \\
\hline 5024 & $48-2$, & $34-136$ & ++ & ++ & + & \\
\hline \multicolumn{7}{|c|}{ Foraminifera recovered by pretreatment wet screening } \\
\hline \multicolumn{2}{|c|}{ Core 12 , Section 3} & \multicolumn{3}{|c|}{$\begin{array}{l}1 \text { Haplophragmoides sp. } \\
2 \text { Ammodiscus } \mathrm{cf} \text {. incertus. }\end{array}$} & \multicolumn{2}{|l|}{$\begin{array}{l}\text { (A) } \\
\text { (A) }\end{array}$} \\
\hline & catcher & $\begin{array}{ll}2 & \text { Dent } \\
1 & \text { Doro } \\
1 & \text { ? Cib } \\
1 & \text { Glob } \\
1 & \text { Glob } \\
1 & \text { Hedt }\end{array}$ & $\begin{array}{l}\text { lina spp. } \\
\text { hia bulletta } \\
\text { cides sp. (? } \\
\text { gerinelloides } \\
\text { truncana cf. } \\
\text { ergella } \mathrm{sp} \text {. }\end{array}$ & $\begin{array}{l}\text { idorsalis sp.) } \\
\text { f. aspera } \\
\text { coronata }\end{array}$ & $\begin{array}{l}\text { (C) } \\
\text { (A) } \\
\text { (C) } \\
\text { (P) } \\
\text { (P) } \\
\text { (P) }\end{array}$ & \\
\hline Core $31, \mathrm{Sec}$ & tion 4 & $\begin{array}{ll}5 & \text { Asta } \\
5 & \text { Lent } \\
1 & \text { Glob }\end{array}$ & $\begin{array}{l}\text { olus sp. } \\
\text { clina sp. } \\
\text { lina sp. }\end{array}$ & & $\begin{array}{l}\text { (C) } \\
\text { (C) } \\
\text { (C) }\end{array}$ & \\
\hline Core $33, \mathrm{Sec}$ & tion 2 & 3 Lent & culina spp. & & (C) & \\
\hline
\end{tabular}

(A) $=$ Agglutinated, benthic; $(\mathrm{C})=$ Calcareous, benthic; $(\mathrm{P})=$ Calcareous, planktonic.

Note: $-=$ Barren, $+=$ Very poor to poor,$++=$ Moderate,$+++=$ Good, $F=$ Fora minifer, $M=$ Megaspores. (Recovered by wet screening before processing.)

although examples of radiate bacterial corrosion were seen in some Upper Cretaceous samples. Species abundances and the floral composition graph were based on counts of 200 specimens per slide, except in Core 17, Section 2, and Core 36, Section 1, where yields were extremely low. Full assemblages were gained by scanning up to three slides in all, covering up to 5,000 specimens. Where results were available from more than one section of a core, they were combined for graphic display.

A total of 194 species has been distinguished. From Figure 2 it can be seen that there is a profound difference between the Upper and Lower Cretaceous floras. Species diversities are low in the Lower Cretaceous with no sample yielding more than 30 species. In contrast, the Upper Cretaceous samples are much richer, with a maximum of 82 species in Core 19. This marked difference requires some explanation. The species diversity curve reflects the interaction of a number of elements such as climate, provenance, miospore preservation, sample yield, and so forth. However, we believe that climate and provenance are probably the most important. The low diversities could then be interpreted to reflect a harsh climate of some sort (cold or low rainfall) and/or a supply of spores and pollen from a restricted area or plant community. The low proportion of fern and fungal spores may indicate a dry climate, but may also simply reflect dilution by pollen from the dominant classopollis vegetation or a variety of other ecological factors. The Upper Cretaceous assemblages, on the other hand, with their much higher diversities, indicate a less harsh climate (warmer, and wetter?) and a source of spores and pollen from a much wider area including more diverse plant communities. These interpretations find support in the floral composition graph (Figure 2). A restricted provenance and a local plant community which supplied organic material to unit 7 are compatible with the great dominance of Classopollis in Cores 27 to 48: Harsh environments are characterized by adaptable species, which achieve dominance through lack of completion. Hughes (1973, p. 190) concluded that the plants producing Classopollis pollen were presumably coniferophytes and grew on the seaward margin of deltas, as mangrove plants do in the present time. There is some correlation between the species-diversity and the composition-of-organic-material graphs. Species diversities are highest in Cores 18, 19, and 20, where the detrital organic material is finest and most abraded, suggesting relatively long transport; it drops in Cores 17 and 13, and in Cores 21 and 24, where coarser material and more cuticular remains suggest closer source areas.

The dominance of Classopollis declines sharply within the Upper Cretaceous, and it becomes a minor element above the middle of the interval. Classopollis classoides types predominate in Unit 7, but in Unit 6 forms comparable with $C$. meyeriana, but bigger, become more important. An echinate-granulate form (Classopollis VI) similar to $C$. perplexus Boltenhagen, 1973, of the Cenomanian in Gabon is also present in Unit 6. Compared to the situation in the Agulhas bank wells, where Inaperturopollenites and Araucariacites pollen grains are common throughout the Lower Cretaceous (unpublished SOEKOR information), these 


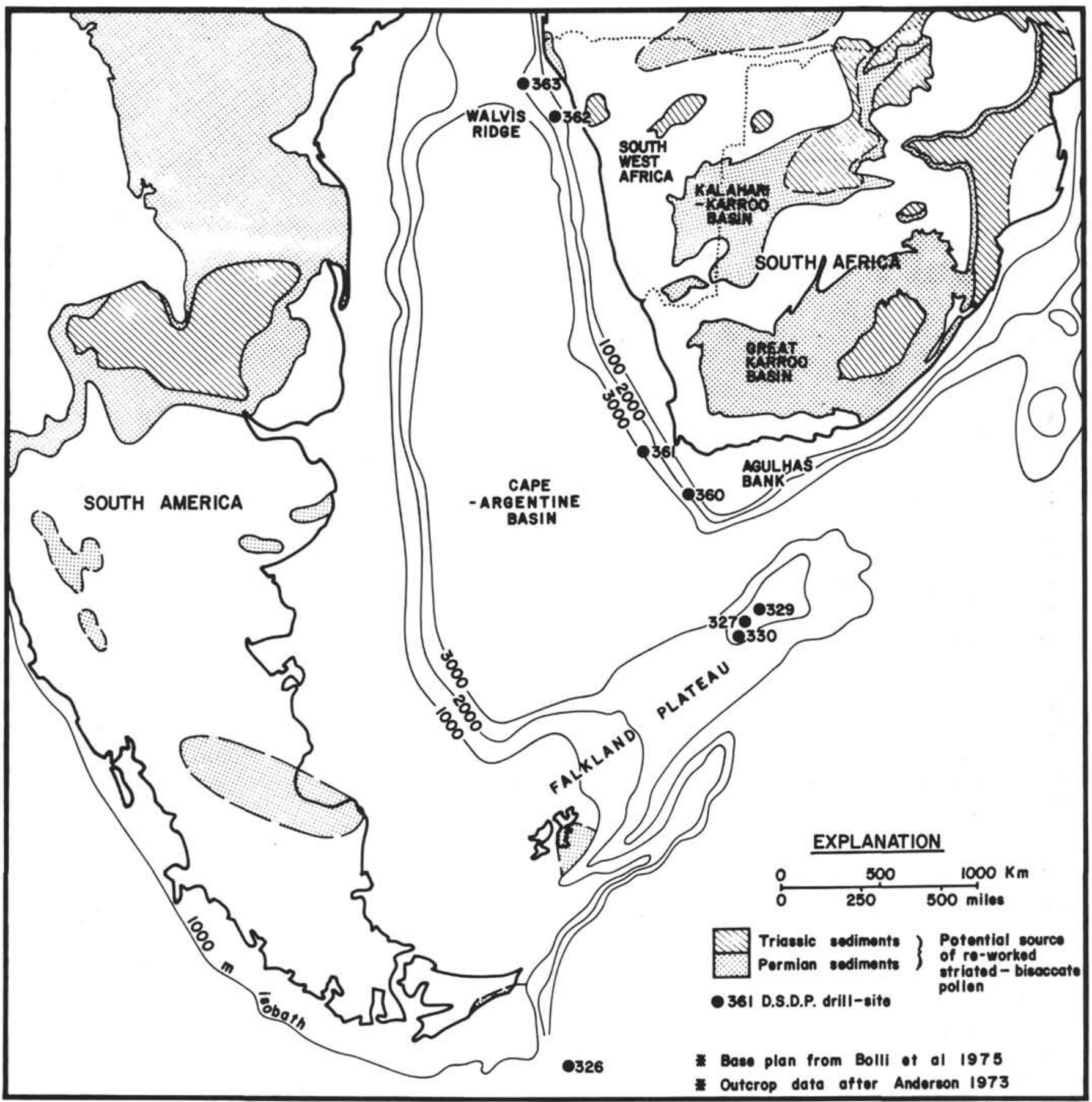

Figure 1. Plan showing the position of Site 361 in the Cape-Argentine Basin in Late Cretaceous time and the present distribution of Permian and Triassic sediments.

two genera are fairly rare at Site 361 . As in described Australian floras, I. limbatus Balme, 1957, is restricted to the Lower Cretaceous (cf. Burger, 1973).

In the saccate flora mono- and bisaccates dominate in the Lower Cretaceous, while trisaccates become more important in the Upper Cretaceous Many of the trilete fern spores in the Lower Cretaceous interval of Site 361 have also been recorded from Australia, but the important species on which the Australian zonations are based, are lacking. These include Pilosisporites, Trilobosporites, Contignisporites, etc.
(Burger, 1973; Dettmann, 1963), which are present however in the Agulhas bank wells (unpublished SOEKOR information). Though few in numbers, many species of Cicatricosisporites and Appendicisporites are present at Site 361 . There are few similarities with the described West African floras, but Zlivisporites blanensis Palct, 1961, recorded by Boltenhagen (1967) from Gabon, are present in the Senonian of Site 361 .

The angiosperms appear very suddenly and in great numbers in Core 24 of lithological Unit 6. Contrary to the sequence of appearance in Australia (Dettmann, 
1973) monocolpates appear earlier than tricolpates. A few Liliacidites and Clavatipollenites specimens are found in the Lower Cretaceous, but their presence is obscured by the abundance of Classopollis. The angiosperm flora consists mainly of tricolpates with simple reticulate ornamentation and is of little use in zoning the Upper Cretaceous, because the key species, such as Nothofagidites used in Australia (Dettmann and Playford, 1966), and Rugubivesiculites used in America (Gray and Groot, 1969), are absent. Of the more important West African pollen (Belsky et al., 1965) only Constantisporis and Andreisporis are found, though they first appear much later in the Senonian. Typical West African Upper Cretaceous pollen such as Aquilapollenites and Galeacornea were not recorded.

\section{Phytoplankton (dinoflagellate cysts and acritarchs)}

Yields of phytoplankton are consistently much lower than of spores and pollen, but the degree of preservation is generally good. The percentage phytoplankton graph in Figure 2 shows persistent low ratios in the Lower Cretaceous, but a marked increase within the Upper Cretaceous. This pattern is in line with the idea expressed in Chapter 2 of this volume, that the supply of terrigenous material-spores and pollen in this case-dwindled during the Late Cretaceous. It is probable, however, that the fall-off is due as much to the greater distance of transport to the depositional site as to reduction of relief in the provenance.

The persistent presence of phytoplankton confirms that sedimentation took place in a marine environment throughout the interval cored at Site 361 ; this is further supported by the presence in nearly all the samples of the acid-resistant chitinous linings of the initial chambers of benthic foraminifer (commonly referred to as "microforaminifers" after Wilson and Hoffmeister, 1952).

Acritarchs form an insignificant proportion of the assemblages. Crassosphaera bella Singh, 1971, is rare but quite conspicuous in Unit 7 and Pterospermella spp. are common in this unit but was not recorded above Core 27. It would be interesting to know whether these palynomorphs are characteristic of the Unit 7 sort of depositional environment elsewhere in the world. Species of Cymatiosphaera and Micrhystridium are both present in small numbers throughout Units 6 and 7.

The presence of the alga Botryococcus within the Late Cretaceous samples is interesting. It typically occurs in shallow, fresh- to brackish-water lakes and pans at the present day. It is most unlikely that it lived in the deep-water conditions of lithological Unit 6, and it was probably transported in with other land-derived organic material. For it to be so consistently represented, it must have been quite abundant in the source area. This could be tentatively taken to imply that the shores at the time were of fairly low relief and that there were extensive areas of brackish-to fresh-water marsh and shallow lakes supporting Botryococcus, which was periodically swept out to sea by floods. Palambages spp. were noted only in the Late Cretaceous (Cenomanian to Turonian?) in Cores 21 to 24. Davey (1970) has reported Palambages in the Albian and Cenomanian of Europe and North America.

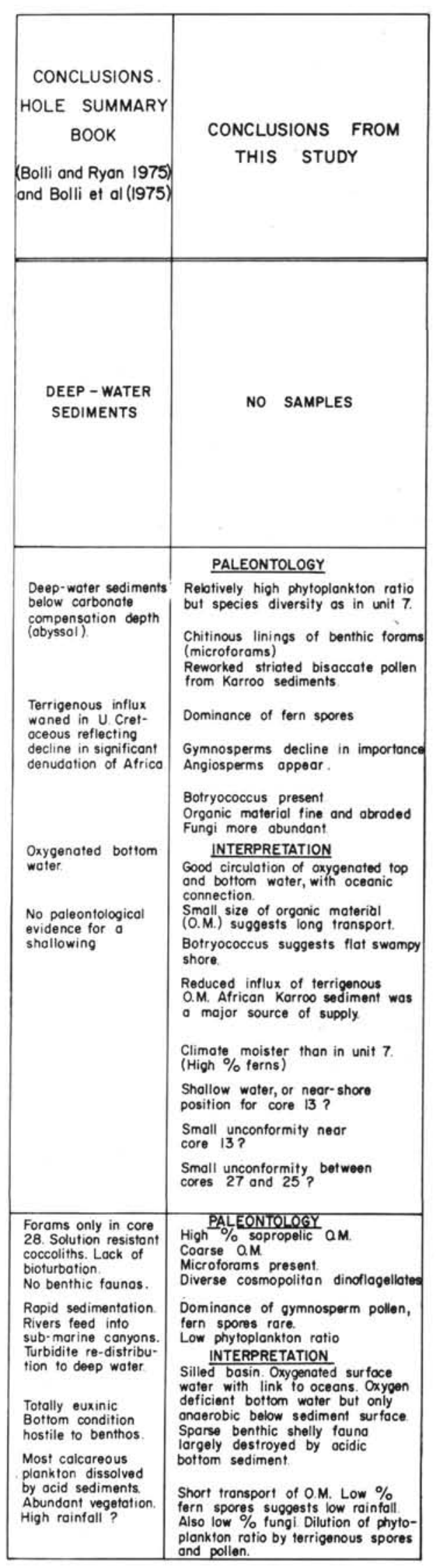

Figure 2. Graphic display of main palynological results, Site 361. 


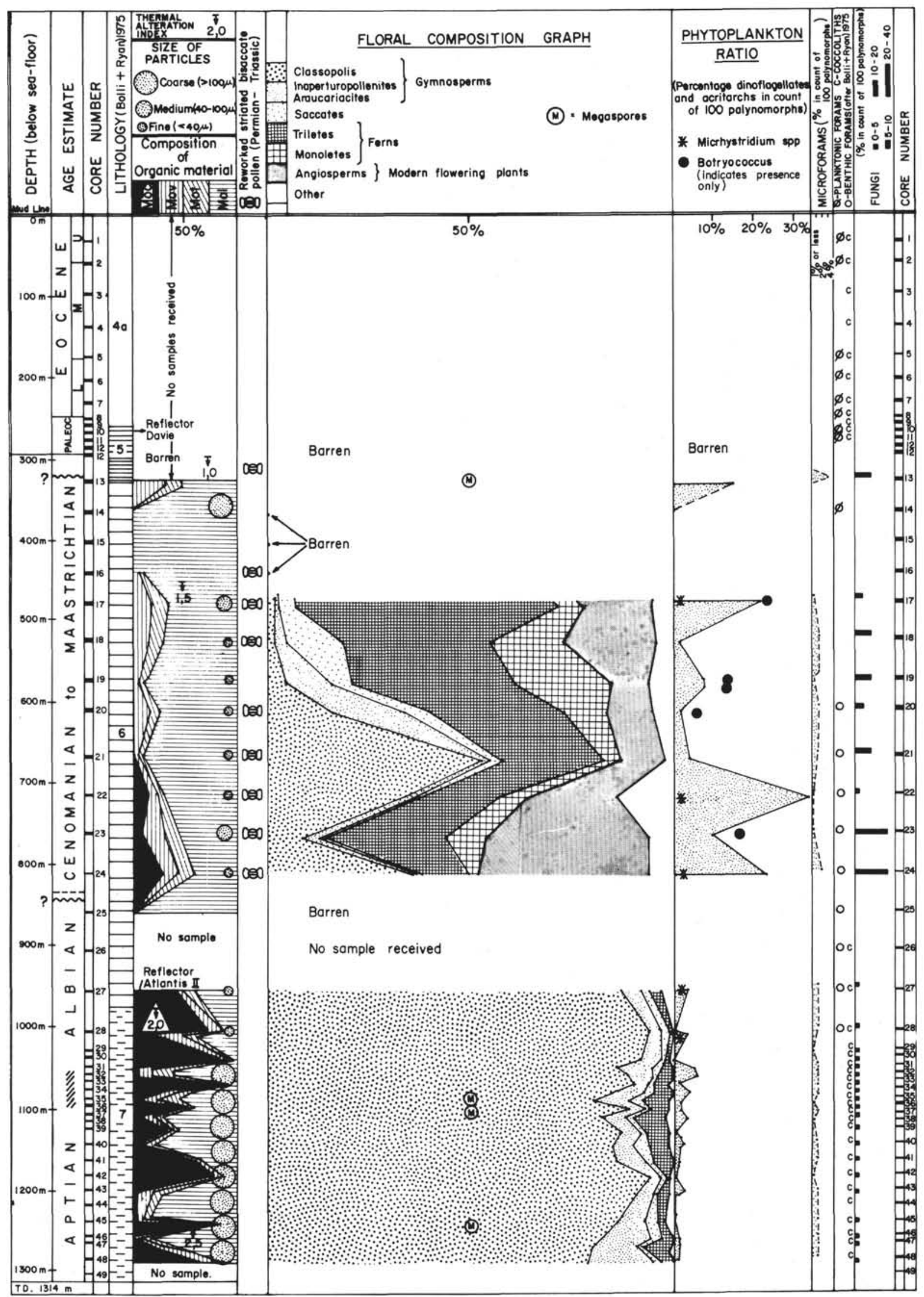

Figure 2. (Continued). 


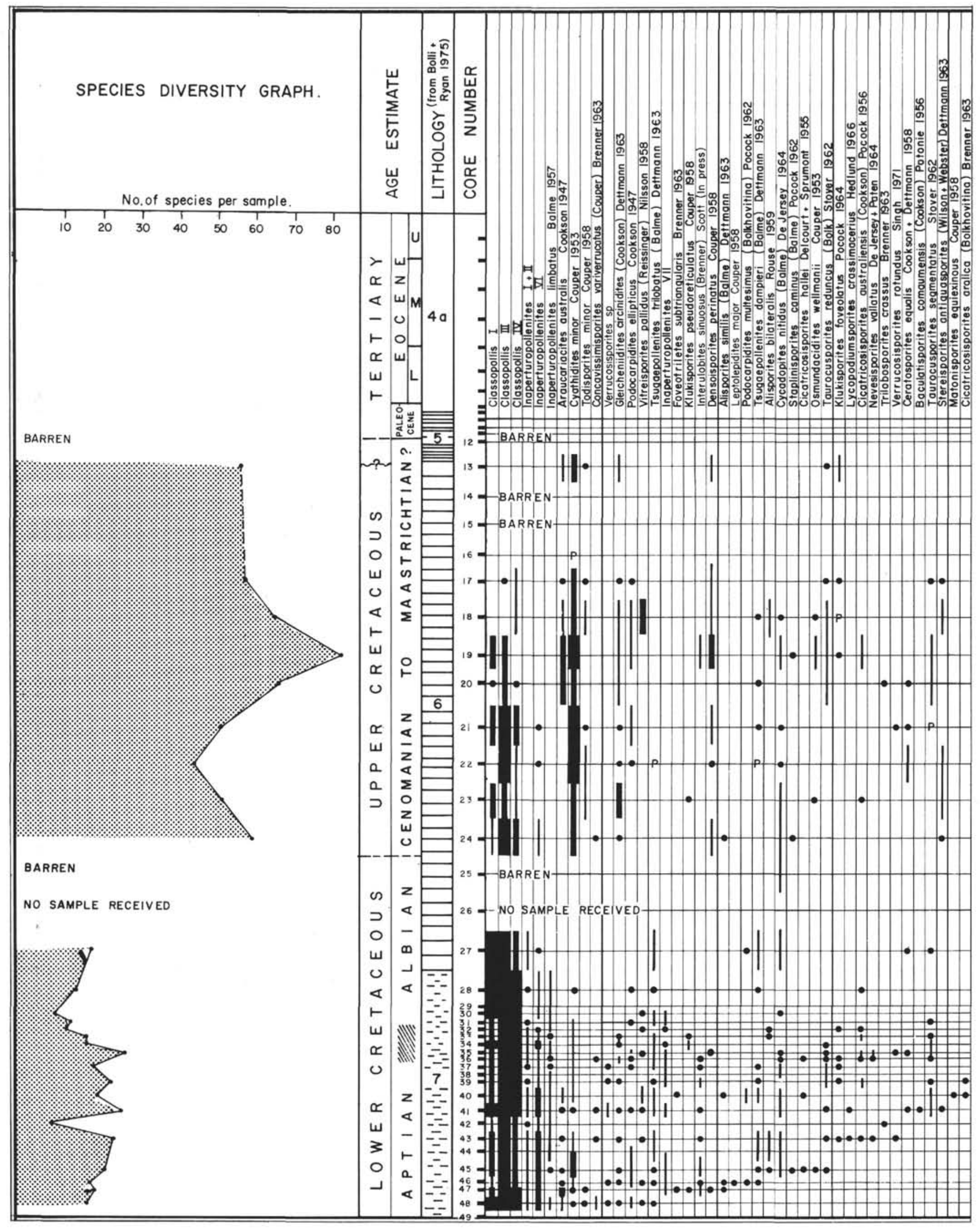

Figure 3. Spore and pollen range chart and species diversity graph, Site 361. 


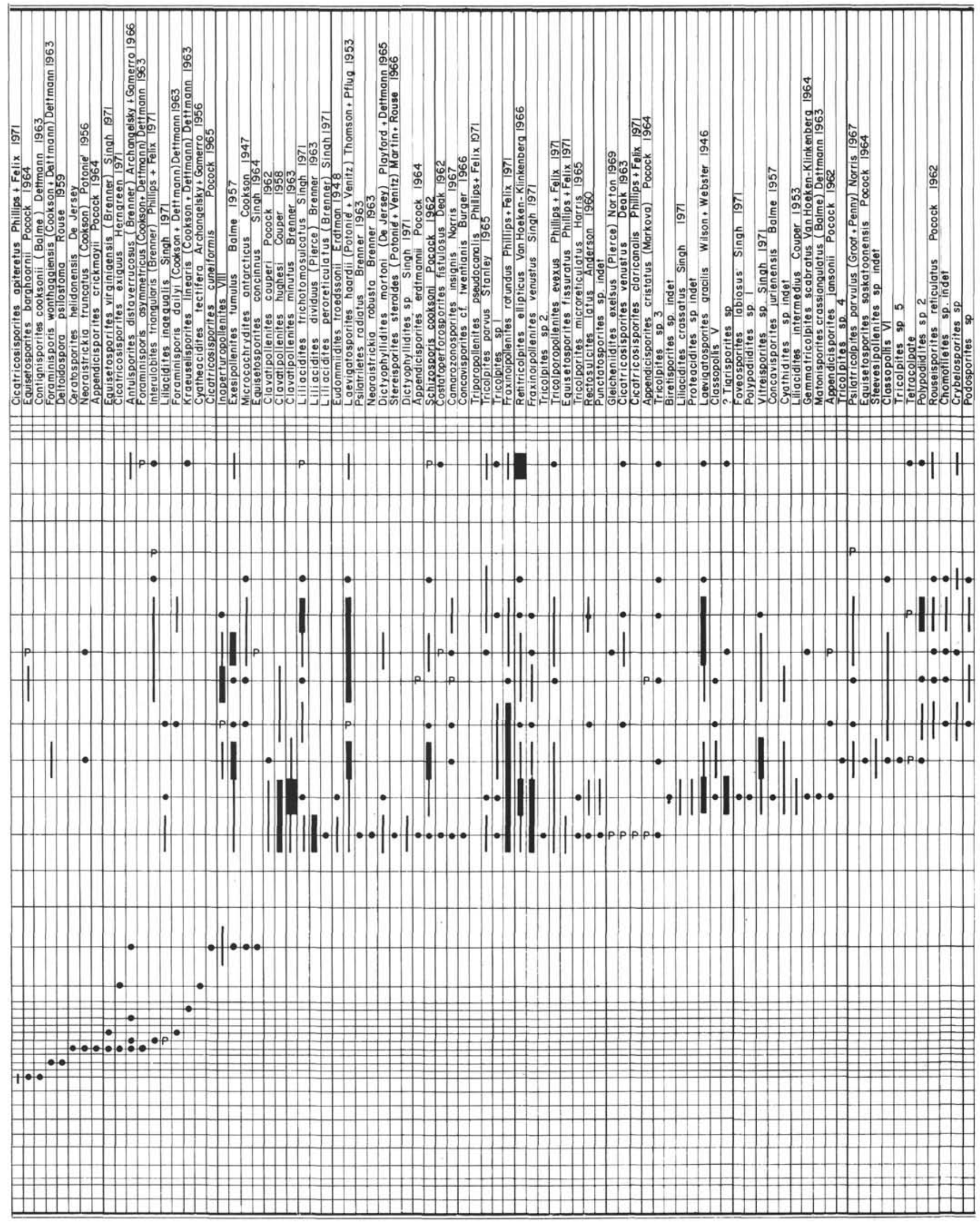

Figure 3. (Continued). 


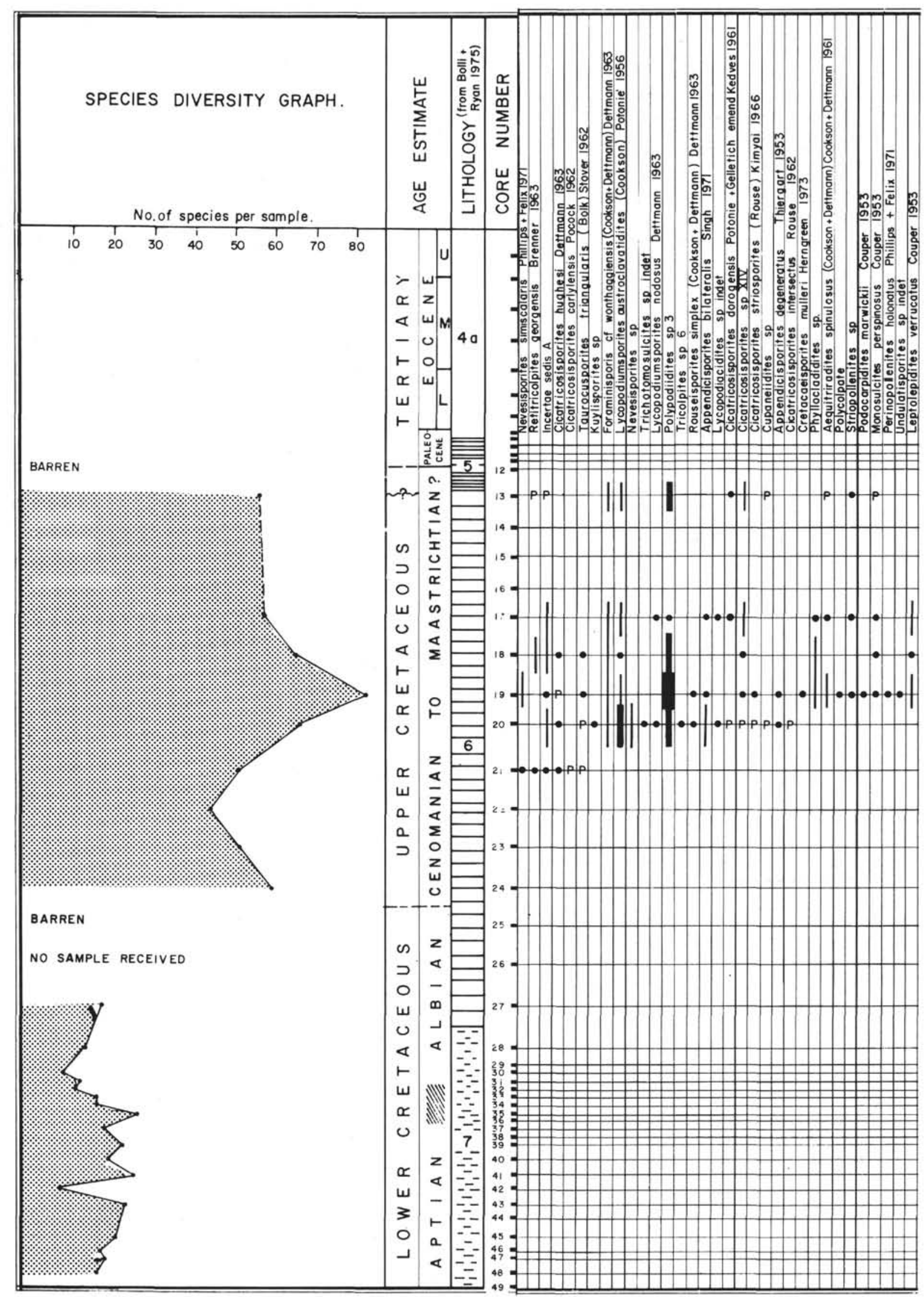

Figure 3. (Continued). 


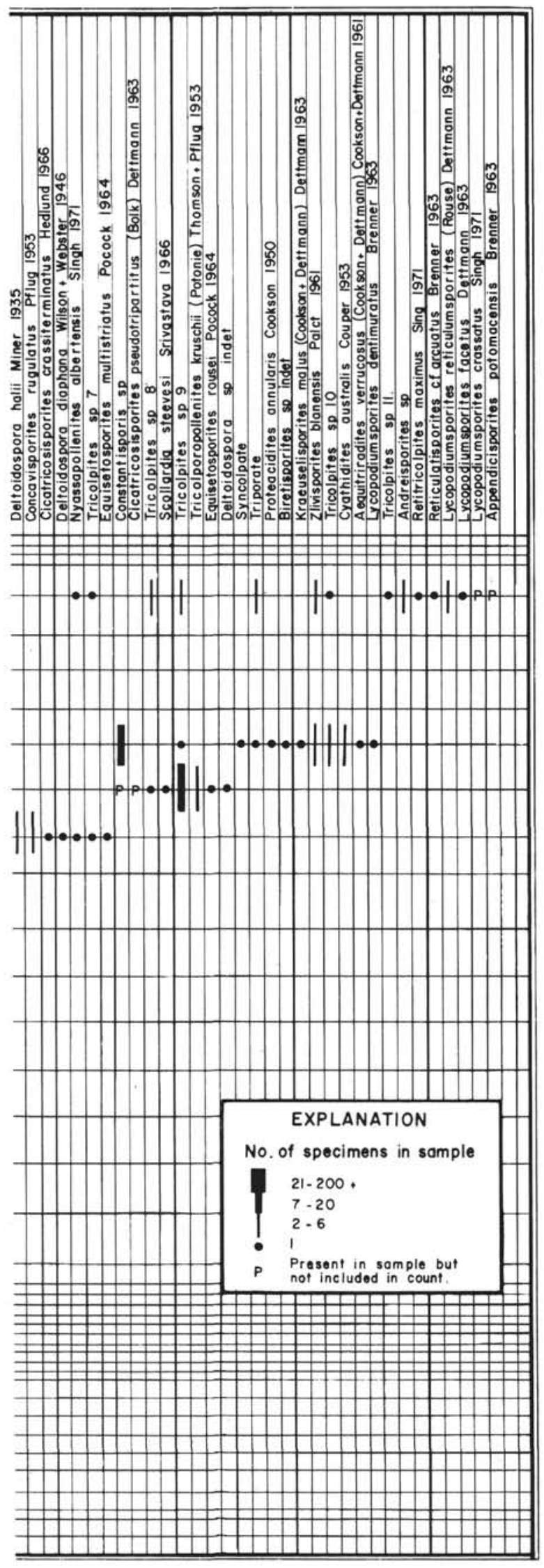

Figure 3. (Continued).
Only the more prominent dinoflagellate cyst species are shown on the accompanying range chart (Figure 4). They indicate clearly that the assemblages of both Upper and Lower Cretaceous are of a cosmopolitan nature and contain species which are familiar in Europe, Australia, and elsewhere in the world. This implies that the surface water of Units 6 and 7 was able to circulate freely and had an effective communication with the oceanic seas. Furthermore, the dinoflagellate species diversity graph (Figure 4) shows that many of the samples from the Lower Cretaceous interval have diversities equivalent to those of the Upper Cretaceous, which adds support to the idea of freely circulating surface water during the time Unit 7 was deposited.

As noted above, microforaminifers are present in most cores. The most common forms show a simple coiled or trochoid chamber arrangement. Uniserial and biserial specimens were noted but are quite rare. Generic and specific identifications of the parent foraminifers are not possible. They are especially significant in those intervals where foraminifers were not reported in the shipboard record (Bolli and Ryan, 1975); it is likely that their original calcareous shells or carbonate-cemented shells were dissolved during early burial. We know of no record of microforaminifers from planktonic species. If this is correct then in Unit 7 they indicate the presence of a benthic microfauna, which in turn implies that the bottom environment was not "totally euxinic" as proposed in Chapter 2. The calcareous benthic foraminifers recovered by us from Cores 31 and 32 (see Table 1) confirm that a shelled benthos is present in at least some of the cores. This interpretation may have a bearing on the origin and deposition of the sediments: we are not entirely convinced that Unit 7 was deposited in particularly deep water. Within Unit 6 the microforaminifers simply record the wider presence of a deep-water microfauna presumably similar to that noted in the shipboard report for Cores 20 to 28 .

\section{Age}

It has not been possible to arrive at an age subdivision that is consistent with the indications of the more important species of Site 361. The placing of many of the boundaries has therefore been rather arbitrary. Because of the paucity of reliable index spores and pollen, we have relied more heavily on the dinoflagellates to derive the breakdown shown in Figure 2. The dinoflagellate ranges shown in Figure 5 were obtained mainly from Williams (1974), Wiseman and Williams (1974), Davey and Verdier (1971, 1973, 1974) and Verdier (1975). The dinoflagellates were plotted against these ranges in the same order of appearance as detailed in Figure 4. By comparing Figures 4 and 5 , it can be seen that the age indications of the species in any particular core sample are commonly in conflict. Nevertheless, although this makes the selection of stage boundaries arbitrary, it can be seen that the dinoflagellates support the age bracket given in the shipboard report and indicate sediments ranging in age from Aptian to Senonian. It has also been possible to make a broad correlation with the 


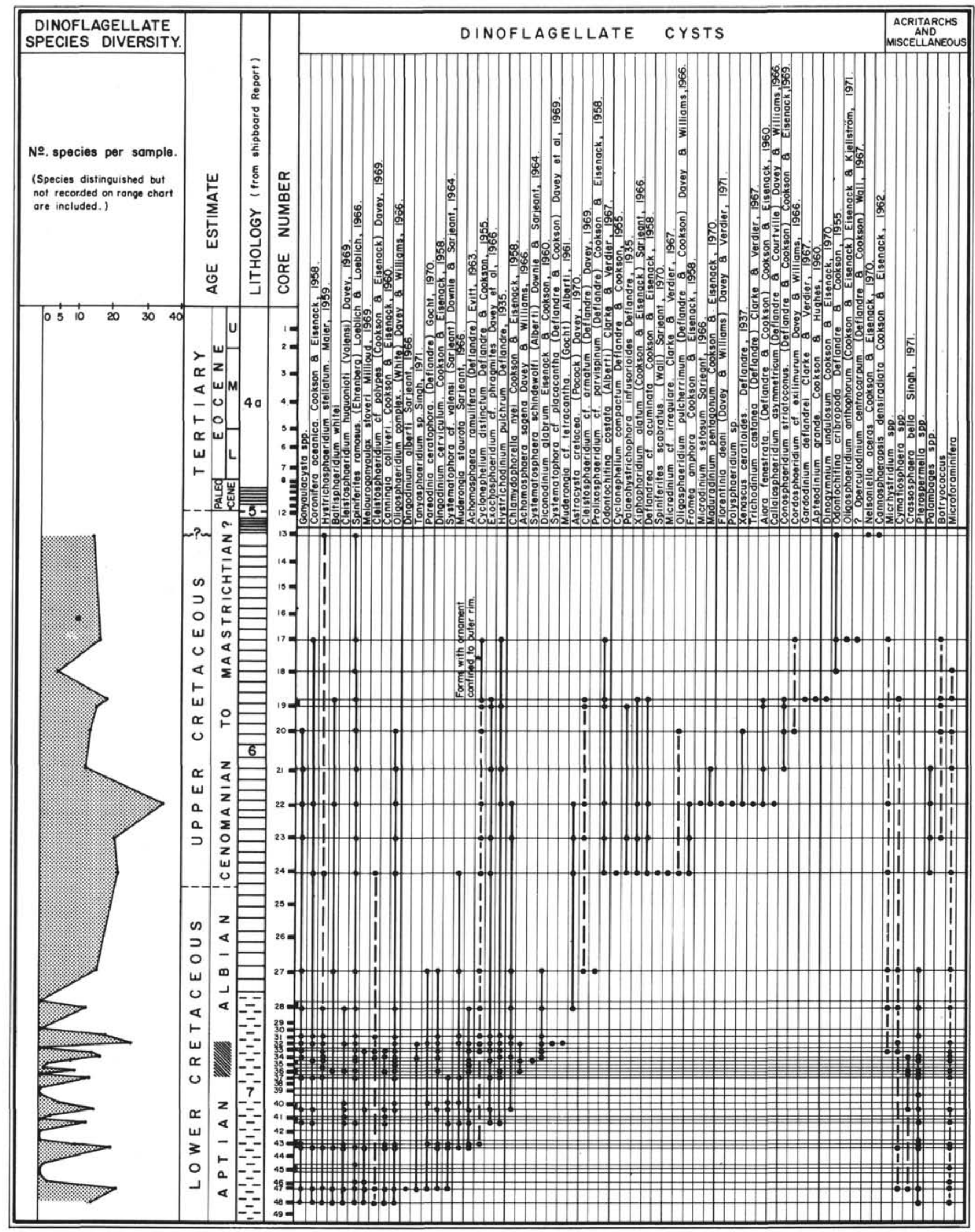

Figure 4. Phytoplankton range chart and species diversity graph, Site 361 . 


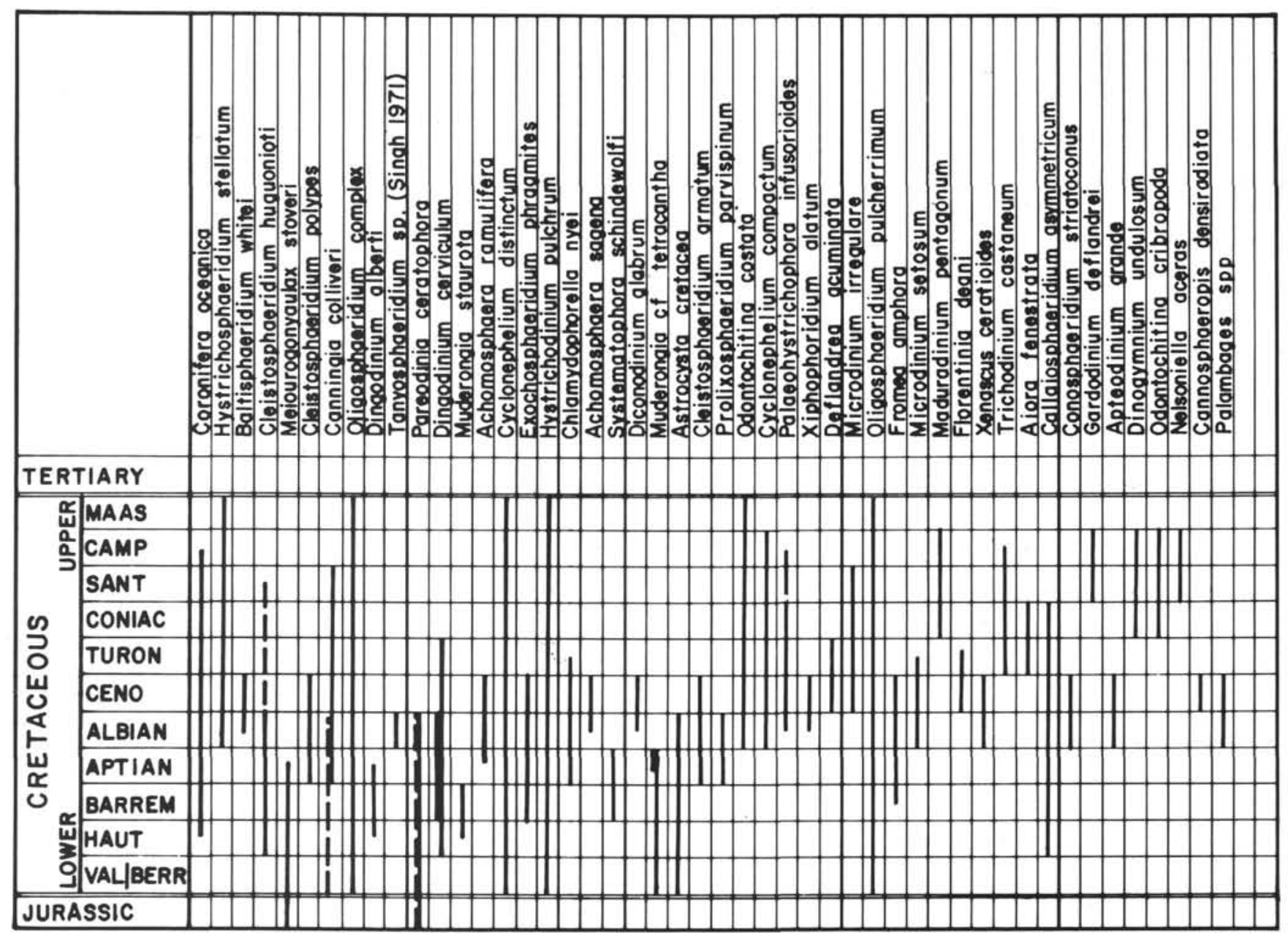

Figure 5. Age ranges of distinctive dinoflagellates at Site 361 plotted in their up-hole order of appearance (cf. Figure 4).

petroleum exploration wells drilled on the Agulhas bank using unpublished SOEKOR information and approximately the same time range is indicated. (Age conclusions in the Agulhas bank wells are based on ostracode and foraminiferal evidence.) Three aspects call for discussion; these are the age of Unit 7, in particular its lowest part, the boundary of the Upper and Lower Cretaceous, and the age of the youngest Cretaceous sediments.

The presence of the following dinoflagellates supports the Aptian-Albian assignment of Unit 7 (see Figures 4 and 5):

Meiourogonyaulax stoveri-Pre-Cretaceous to Lower Aptian.

Dingodinium alberti-Mid-Hauterivian to Lower Aptian.

Tanyosphaeridium sp. (Singh, 1971)_Albian.

Pareodinia ceratophora-Pre-Cretaceous to Albian.

Dingodinium cerviculum-Barremian to Albian (shorter range of Wiseman and Williams, 1974).

Chlamydophorella nyei-Aptian to lower Turonian. Systematophora schindewolfi-Barremian to Aptian. Diconodinium glabrum-Upper Albian to Cenomanian.

Muderongia staurota of upper Hauterivian to upper Barremian age could be cited in support of the presence of upper Barremian but as it first occurs some distance above the bottom of the hole in association with a typical Aptian assemblage, it seems more likely that its range extends into the Aptian and even higher. There is some support for a division between Aptian and Albian in the vicinity of Cores 36 to 32 but lack of agreement of age ranges precludes allocation of a firm boundary. Last appearances of Systematophora schindewolfi, Meiourogonyaulax stoveri, and Dingodinium alberti and first appearances of Achomosphaera ramulifera and Chlamydophorella nyei suggest that the lower part of Unit 7 is Aptian. First appearances of Achomosphaera sagena and Diconodinium glabrum can be cited in support of an Albian age for the upper part of Unit 7.

There is a profound change in the composition of the flora between Cores 27 and 24. Because of the lack of palynological information from Cores 26 and 25 it seemed best to adopt the position of the Upper-Lower Cretaceous boundary shown by Bolli et al. $(1975$, p. 24) just below Core 24 . Unfortunately the palynology supplies little definitive information. Simple reticulate tricolpate and trichotomosulcate angiosperm pollen makes its first appearance in the international record in about mid-Albian time. Its abrupt appearance in Core 24 suggests that the sediments are younger than upper Albian. The international first appearance of the 
dinoflagellates Odontochitina costata, Cyclonephelium compactum, Palaeohystrichophora infusorioides, Xiphophoridium alatum is upper Albian but at Site 361 where they appear in Core 24 it can be assumed that the lack of information from Cores 25 and 26 (upper Albian?) explains their late record. It does not seem practicable to attempt to distinguish stage boundaries within the Upper Cretaceous interval on the information available. There is no suggestion of any erosional or depositional gap in the record and the palynomorphs provide support for the Cenomanian to Maestrichtian allocation of Bolli et al. (1975). It is possible that a part of the Maestrichtian is missing. In wells drilled on the Agulhas bank, microfaunal information suggests a widespread regression within the upper Maestrichtian, and there seems to be a distinct but minor unconformity at the top of the stage (McLachlan et al., in press). The depositional environment of Core 13 is interpreted here as being significantly nearer source and perhaps shallower than that of the rest of Unit 6, so the same situation may apply at Site 361 .

\section{Assessment of Organic Residue}

For this study only slides of unoxidized unstained residue were used. Results are shown in Figure 2. The organic residue of each sample has been examined and the components classified according to the categories used by Correia (1971, p. 610), with slight modification viz:

MOC-Amorphous or colloidal sapropelic material. MOV-Cuticular plant tissue, including spores, pollen, fungi, phytoplankton.

MOT-Plant tracheid or other dense structured land plant material, usually of a dark orange or brown color.

MOL-Apparently structureless lignitic material; this includes micrinite, fusainite, and mineral charcoal.

The shaly samples of lithological Unit 7 yielded very high proportions of sapropelic organic material, indicating strongly reducing bottom sediment conditions; the siltier or sandier-and presumably better oxygenated-samples contained much less sapropel and relatively high proportions of lignite. The reducing bottom conditions seem to have persisted through into Unit 6 , as Cores $27,24,23$, and 22 all contain small proportions of sapropel. The floral composition of Core 27 suggests a greater similarity with the Unit 7 samples than with those of Unit 6 . The increase in lignitic material upward into Unit 6, indicates increasingly oxygenated conditions, since lignite resists destruction by oxidation more effectively than any of the other types of organic material.

The average size of the derital particles of organic material shows some interesting trends (Figure 2). Within lithological Unit 7 the material is relatively coarse $(>100 \mu \mathrm{m})$, implying that it has not been subjected to much breakage or abrasion during transport; it probably accumulated fairly near source. On the other hand, the particle size is generally fine within Unit $6(<40 \mu \mathrm{m})$; tracheid and lignitic fragments are usually quite well rounded and are interpreted to have been abraded during transport. This is compatible with the deep-water distal depositional environment postulated in the shipboard report. There are exceptions to this pattern. Core 23 has relatively coarser detrital organic material and a reduced phytoplankton content, Botryococcus is present, and the content of fungal spores is relatvely high. We interpret this to record a regression with a (?) shallower water depth and a reduction in transport distance. A similar situation is indicated by the sample from Core 17 . Results from Core 13 are even more striking: the residue contains a relatively large proportion of plant cuticle, and sporongia with numbers of spores still in place are conspicuous, together with a variety of other delicate cuticular material. It is difficult to reconcile these features and the information given in the section above dealing with age, with the deep-water depositional environment suggested in the shipboard report and in Bolli et al. (1975); we prefer to visualize a quiet, shallow-water, near-shore environment.

A further application of this study is the assessment of the potential of the sediments as petroleum source rocks, using the techniques outlined by Correia (1971) and others. Assuming a correspondingly high total organic content, which seems reasonable from the shipboard report, the high sapropel (MOC) content of the 300-meter-thick shales of Unit 7 indicates a good oil-generating potential. The color of the organic material can be used to estimate the maximum temperature to which the sediments have been subjected and hence the "maturity" of the source rocks (Correia, 1971); with increasing temperatures, volatile components are progressively lost, resulting in an increase in the carbon content of the material and a corresponding darkening of color. We have used the five-step scale of Correia (1971, table III), which follows the changing color of spores, pollen, and other organic material from pale translucent yellow, through orange and brown to black. The scale units are referred to here as "thermal alteration indices" or TAIs. The results for Site 361 are shown in Figure 2. The highest sample (Core 13) is barely altered; spores, pollen, and phytoplankton remain generally pale yellow to yellow and translucent down to the top of Unit 7, where some darkening becomes apparent. Only the last 50 meters of the unit is approaching the upper limit at which oil might have been generated (TAI 2.5). This lithological unit is said in the shipboard report to thicken shorewards. Where it is more deeply buried ( $\pm 500 \mathrm{~m}$ more) and thicker, it could have acted as a significant petroleum source rock.

An interesting feature concerning the color of the miospores is the presence in Unit 7 of darkened spores and pollen with TAIs ranging from 2.5 (orange) to 4 (brown-black). Indentifiable specimens belong to the same species as their pale in situ equivalents in the same slides. No darkened phytoplankton was observed, so the possibility of carboniation by accidental overheating during laboratory processing can be discounted. The fact that the darkened miospores belong to the same species as the paler material in the same slides also refutes the possibility of it being reworked older Cretaceous material. It is tentatively suggested that the darker miospores are the result of forest fires. This would account for the variable darkening, the common speciation, and the lack of 
darkened phytoplankton. Dark, opaque yellow-orange (TAI 3.00-3.5) generally distinctly marked, striated bisccate pollen grains were detected within Unit 6 samples (Figure 2); they probably derive from the sediments in the Karoo basin in South Africa (Figure 1). The organic material in the lower Permian Dwyka and Ecca Groups in the southern half of the basin has everywhere been strongly carbonized (brown-black to black, TAI 4a-5) and the same situation holds for the southwestern part of the Kalahari Karoo basin (personal observation). The color of the striated bisaccates in the Site 361 sediments indicates that they originated from sediments that were not strongly heated as a result of dolerite intrusion or deep burial. They are equivalent in color to pollen from the northern part of the Karoo basin which is estimated to have been buried not deeper than 1500 to 2000 meters. The source of the bisaccates was probably carbonaceous facies of Permian to Triassic age in the southwestern Cape.

It is surprising that no reworked Karoo palynomorphs were seen in the Unit 7 residues, but their absence perhaps can be explained by the suggested very local source for the sediments of this unit. It would be interesting to know what climatic and physical conditions are necessary to allow the weathering, erosion, transport, and deposition without destruction, of reworked palynomorphs. Palynomorphs and cuticle are usually absent from even apparently fresh outcrop samples of both Paleozoic and Mesozoic sediments in South Africa.

\section{ADDENDUM}

\section{Notes on spores and pollen}

A list of the spores and pollen recorded can be found in the range chart on Figure 3. The absence of adequately preserved specimens for photography prevented the illustration of some species. Descriptive or taxonomic notes are only given in a few cases as the majority of the species accord well with the descriptions in the literature.

\section{Classopollis spp.}

Because of the difficulties involved, no attempt was made to speciate Classopollis, though several species are represented. For convenience the following broad grouping was used.

Classopollis I C. meyeriana-type. Smooth, solid appearance with no or only minor infrastructure. 23-38 $\mu \mathrm{m}$ diameter.

Classopollis III C. classoides-type. With conspicuous infrastructure and prominent striae near the equator. 25-35 $\mu \mathrm{m}$ diameter.

Classopollis IV Much like C. III but with less clear structure and generally smaller. 22-32 $\mu$ m diameter.

Classopollis $V$ Very fine infrastructure with radial folds round the periphery giving it a frill-like appearance. 28-30 $\mu$ m diameter.

Classopollis VI Echinate-granulate form comparable to C. perplexus, Boltenhagen 1973.

\section{Inaperturopollenites spp.}

The genus Inaperturopollenites was not speciated, but the following grouping based on a few outstanding characteristics, was used:

Inaperturopollenites I \& II Thin to medium wall with a thinned or thickened area in the center; smooth.

Inaperturopollenites VI Subequatorial fold; smooth.

Inaperturopollenites VII Very thick wall; smooth.

Inaperturopollenites VIII Granulate.

\section{Densoisporites}

There may be more than one species of Densoisporites, but because it is impossible to find sharp distinctions, all were retained under $D$. perinatus.

\section{Trilobosporites and Contignisporites}

Only a few specimens (one Contignispores and two Trilobosporites) were found and thus were not regarded as stratigraphically significant.

\section{?Tigrisporites}

Although the specimen resembles Tigrisporites, no distal polar thickening can be seen as is required in the generic diagnosis.

\section{Cyathidites sp.}

This specimen possesses fine spines both proximally and distally. $24 \mu \mathrm{m}$ in diameter.

\section{Zlivisporites}

Zlivisporites differs from Lycopodiumsporites in having a flange and a distal reticulum that does not continue onto the flange (Boltenhagen, 1967).

\section{Cicatricosisporites}

C. apiteretus differs from $C$ australiensis only by having a solid area at the corners, whereas $C$. australiensis has a notched appearance.

\section{Cicatricosisporites XIV}

Amb triangular with rounded corners. Laesurae straight, with membranous lips and reaching $\pm 3 / 4$ of spore radius. Distal face with ribs parallel to sides of amb, forming a triangle in the center. Proximally the ribs run subparallel to one laesura and oblique to the other one in each contact face, leaving a very small, smooth area next to the laesurae. The ribs are not straight but curve round the spore at the equator. At the corners the ribs fuse to form solid areas. Ribs $3 \mu \mathrm{m}$ wide, canals $0.8 \mu \mathrm{m}$ wide. A narrow groove runs down the center of each rib.

Dimensions: 56 (65) $80 \mu \mathrm{m}$ (6 specimens).

Remarks: No fossil spore with the characteristic narrow groove in the center of the ribs could be found in the available literature, but a similar feature is seen in recent Mohria spp. (Welman, 1970).

\section{Incertae sedis A}

Outline circular. Porate. Inner body with scattered spines on proximal side. No stratification distinguishable in wall. Distal side psilate with heavy, 
raised ornamentation. This consists of muri $\sim 2 \mu \mathrm{m}$ in diameter forming an irregular curvimurate reticulum or terminating freely to form a maze. Round the equator it forms a perfect circle. The ornamentation is connected to the inner body by pillars of $\sim 1 \mu \mathrm{m}$ diameter. The muri are chagrinate and opaque light yellow.

Dimensions: 32 (34) $36 \mu \mathrm{m}$ (5 specimens).

\section{Angiosperms}

The pollen grains were, where possible, given names of species already described in the literature, although the latter does not form a coherent system. Those that could not be identified were grouped together under Tricolpites spp. 1-11.

\section{ACKNOWLEDGMENTS}

We are indebted to Dr. W. Siesser who encouraged the study, provided the samples, and made available early results of the shipboard report and also to Professor $\mathrm{H}$. Bolli who has been most generous with his assistance and advice. Material was processed in the SOEKOR laboratories, which are maintained at the Bernard Price Institute for Palaeontological Research. Dr. H. Winter, Dr. A. de Swardt, and Mr. S. van Wyk of Soekor and Dr. Ann Anderson of the Bernard Price Institute discussed various aspects of the work and critically reviewed the manuscript. Mr. I.K. McMillan of SOEKOR made identifications of foraminifers and microforaminifers.

The Management of SOEKOR is thanked for providing the time and facilities which were devoted to the study.

\section{REFERENCES}

Anderson, J.M., 1973. The biostratigraphy of the Permian and Triassić. Palaeont. Afr., v. 16, p. 59-83.

Belsky, C.Y., Boltenhagen, E., and Potonié, R., 1957. Sporae dispersae der Oberen Kreide van Gabun, Aquatoriales Afrika: Paläont. Z., v. 39 , p. $72-83$.

Boltenhagen, E., 1967. Spores et Pollen du Cretacé Superieur du Gaboń. Pollen et Spores, v. 9, p. 331-355.

1973. Quelques espéces du genre Classopollis (Pflug). Reyere du Crétacé Supérieur du Gabon: Rev. Micropaleontol., v. 16, p. 205-213.

Burger, D. 1973. Spore zonation and sedimentary history of the Neocomian, Great Artesian Basin, Queensland: Spec. Publ. Geol. Soc. Australia, v. 4, p. 87-118.

Correia, M., 1971. Diagenesis of sporopollenin and other comparable organic substances: application to hydrocarbon research. In J. Brooks et al. (Eds.), Sporopollenin. London and New York (Academic Press), p. 569-620.

Davey, R.J. and Verdier, J.P., 1971. An investigation of microplankton assemblages from the Albian of the Paris basin: Verhandl. Koninkl. Ned. Akad. Wetenschap, Afdel. Natuurk. Sect. 1, v. 26, p. 1-58. 1973. An investigation of microplankton assemblages from latest Albian (Vraconian) sediments: Rev. Española Micropaleontol., v. 5, p. 173-212. 1974. Dinoflagellate cysts from the Aptian type sections at Gargas and La Bedoule, France: Palaeontology, v. 17, p. 623-653.

Dettmann, M.E., 1963. Upper Mesozoic microfloras from southeastern Australia: Proc. Roy. Soc. Victoria, v. 77, p. 1-148.

1973. Angiospermous pollen from Albian to Turonian sediments of Eastern Australia: Spec. Publ. Geol. Soc. Australia, v. 4, p. 3-34.

Dettmann, M.E. and Playford, G., 1969. Palynology of the Australian Cretaceous-A review. In Stratigraphy and Palaeontology: Essays in honour of Dorothy Hill: Canberra, (Australian National University Press), p. 174210.

Gray, T.C. and Groot, J.J., 1966. Pollen and spores from the marine Upper Cretaceous formations of Delaware and New Jersey: Palaeontographica Abt. B., v. 117, p. 114134.

Hughes, N.F., 1973. Palynological time-correlation of English Wealden with boreal marine successions. In Casey, R. and Rowson, P.F. (Eds.), The Boreal Lower Cretaceous: Geol. J. Liverpool Spec. Issue No. 5: (Seal House Press), p. 185-192.

McLachlan, I.R., McMillan, I.K., and Brenner, P.W., in press. Preliminary microfaunal biostratigraphy of the Mesozoic-Cenozoic sediments of the Agulhas bank, Republic of South Africa: 7th African Micropal. Colloquim, Ile-Ife, Nigeria, 1976.

Scott, L., in press. Palynology of Lower Cretaceous deposits from the Algoa basin (Republic of South Africa).

Shipboard Party, 1975. Basins and margins of the eastern South Atlantic: Geotimes, v. 20, p. 22-24.

Verdier, J.P., 1975. Les kystes de dinoflagellës de la section de Wissant et leur distribution stratigraphique au Crétacé moyen: Rev. Micropaléntol., v. 17, p. 159-163.

Welman, W.G., 1970. The South African fern spores. In van Zinderen-Bakker sr., E.M. (Ed.), South African pollen grains and spores VI: Cape Town, p. 1-20.

Williams, G.L., 1974. Dinoflagellate and spore stratigraphy of the Mesozoic-Cenozoic, offshore eastern Canada: Geol. Surv. Canada, Paper 74-30, v. 2, p. 107-161.

Wilson, L.R. and Hoffmeister, S., 1952. Small foraminifera. Micropaleontologist, v. 6, p. 26-28.

Wiseman, J.F. and Williams, A.J., 1974. Palynological investigation of samples from Sites 259, 261 and 263, Leg 27, Deep Sea Drilling Project. In Veevers, J.J., Heirtzler, J.R., et al., Initial Reports of the Deep Sea Drilling Project, Volume 27: Washington (U.S. Government Printing Office), p. 915-924. 



\section{PLATE 1}

All figures are magnified $\times 500$. Additional information in following order: Negative Number; Core Number; Sample Number; Coordinates on Zeiss photomicroscope mechanical stage.

Figure $1 \quad$ Cyathidites minor Couper, 1953, -22982; 24; 4991b.1; 116.5/16.5

Figure $2 \quad$ Cyathidites sp., -23048; 23; 4990b; 122/15.

Figure 3 Deltoidospora sp., -22995; 18; 4984b; 120.6/20.

Figure 4 Deltoidospora hallii Miner, 1935, -23001; 19; 4986b; 103.5/10.5.

Figure $5 \quad$ Biretisporites sp., -23058; 23; 4990b; 115/22.3.

Figure $6 \quad$ Psilatriletes radiatus Brenner, 1963, -23075; 24; 499lb; 78/20.5.

Figure $7 \quad$ Concavisporites juriensis Balme, 1957, -23049; 23; 4990b; 76/15.

Figure $8 \quad$ Stereisporites steroides (Potonié and Venitz) Martin and Rouse, 1966, -23072; 24; 4991b; 97/18.7.

Figure 9 Stereisporites antiquasporites (Wilson and Webster) Dettmann, 1963, -23055; 23; 4990b; 96/16.5.

Figure $10 \quad$ Matonisporites equiexinous Couper, 1958, -23097; 40; 5011b; 117/21.

Figure $11 \quad$ Todisporites minor Couper, 1958, -23054; 23; 4990b; 75/17.6.

Figure 12 Dictyophyllidites sp., -23070; 24; 4991b; 78/16.7.

Figure 13 Dictyophyllidites mortoni (De Jersey) Playford and Dettmann, 1965, -23073; 19; 4986b; 98.3/17.5.

Figure $14 \quad$ Undulatisporites sp., -23005; 19; 4985b; 115.3/9.5.

Figure $15 \quad$ Leptolepidites verrucatus Couper, 1953, -23003; 19; 4985b; 113.4/7.7.

Figure $16 \quad$ Leptolepidites major Couper, 1958, -22976; 47; 5023b; 87/5.

Figure 17

Figure 18

Figure 19

Figure 20

Figure 21

Figure 22

Figure 23

Osmundacidites wellmanii Couper, 1958, -23114; 45; 5020a; 100/21.

Baculatisporites comaumensis (Cookson) Potonié, 1956, -23102; 41; 5014b; 115/9.5.

Conavissimisporites variverrucatus (Couper) Brenner, 1963, -23122; 48; 5024b.1; 124/18.3.

Verrucosisporites rotundus Singh, 1964, -23104; 43; 5016b; 90.5/14.

Verrucosisporites sp., -22977; 41; 5012b; 92.8/14.

Ceratosporites equalis Cookson and Dettman, 1958, -23103; 41; 5014b; 95.4/20.5.

Figure 24

Ceratosporites helidonensis De Jersey, -23090; 35; 5002b; 106/19.

Figure 25

Neoraistrickia robusta Brenner, 1963, -23074; 24; 4991b; 85/18.

Figure 26

Figure 27

Neoraistrickia truncatus (Cookson) Potonié, 1956, -23089; 22; 4989b; 96.4/20.9.

Figure 28

Antulsporites distaverrucosus (Brenner) Archangelsky and Gamerro, 1966, -23085; 31; 4997b; 79/22.7.

Foraminisporis asymmetricus (Cookson and Dettman) Dettman, 1963, -23084; 13; 4978a; 124/11.

Figure 29

Foraminisporis wonthaggiensis (Cookson and Dettman) Dettmann, 1963, -23029; 20; 4987b; 98/21.

Figure 30

Foraminisporis dailyi (Cookson and Dettmann) Dettmann, 1963, -23082; 18; 4984b; 119.3/20.3.

Figure 31

Nevesisporites vallatus De Jersey and Paten, 1964, -23107; 43; 5017b; 103/10.

Figure 32

Figure 33

Nevesisporites sp. proximal view, -23026; 20; 4987b; 122/22.

Nevesisporites sp. median view, -23027; 20; 4987b; 122/22.

Figure 34

Figure 35

Nevesisporites simiscalaris Phillips and Felix, 1971, -23040; 19; 4985b 120/9.

Interulobites sinuosus (Brenner) Scott (in press) -23117; 43; 5018b; 82/9.4.

Figure 36

Interulobites triangularis (Brenner) Phillips and Felix, 1971, -23083; 34; 5001b; 122.4/19.6.

Figure 37

Taurocusporites triangularis (Bolk) Stover, 1962, -23031; 18; 4984b; 79.4/16.

Figure 38

Taurocusporites reduncus (Bolk) Stover, 1962, -23113; 35; 5002b; 120/8.4.

Figure 39

Taurocusporites segmentatus Stover, 1962, -23101; 39; 5009b; 102.7/21.8.

Figure 40

Kuylisporites sp. -23030; 20; 4987b; 99/17.7.

Figure 41

Gleicheniidites exelsus (Pierce) Norton, 1969, -23062; 19; 4985b; 81/20.

Figure 42

Gleicheniidites circinidites (Cookson) Dettmann, 1963, -23059; 23; 4990b; 89/21.4.

Figure 43

Camarozonosporites insignis Norris, 1967, -23067; 21; 4988b; 116/21.

Figure 44

Lycopodiacidites sp., -23014; 20; 4987b; 101/17.8.

Figure 45

Crybelosporites sp., -23043; 21; 4988b; 103/22.

Staplinisporites caminus (Balme) Pocock, 1962, -23071; 24; 4991b; 99/18.5. 
PLATE 1
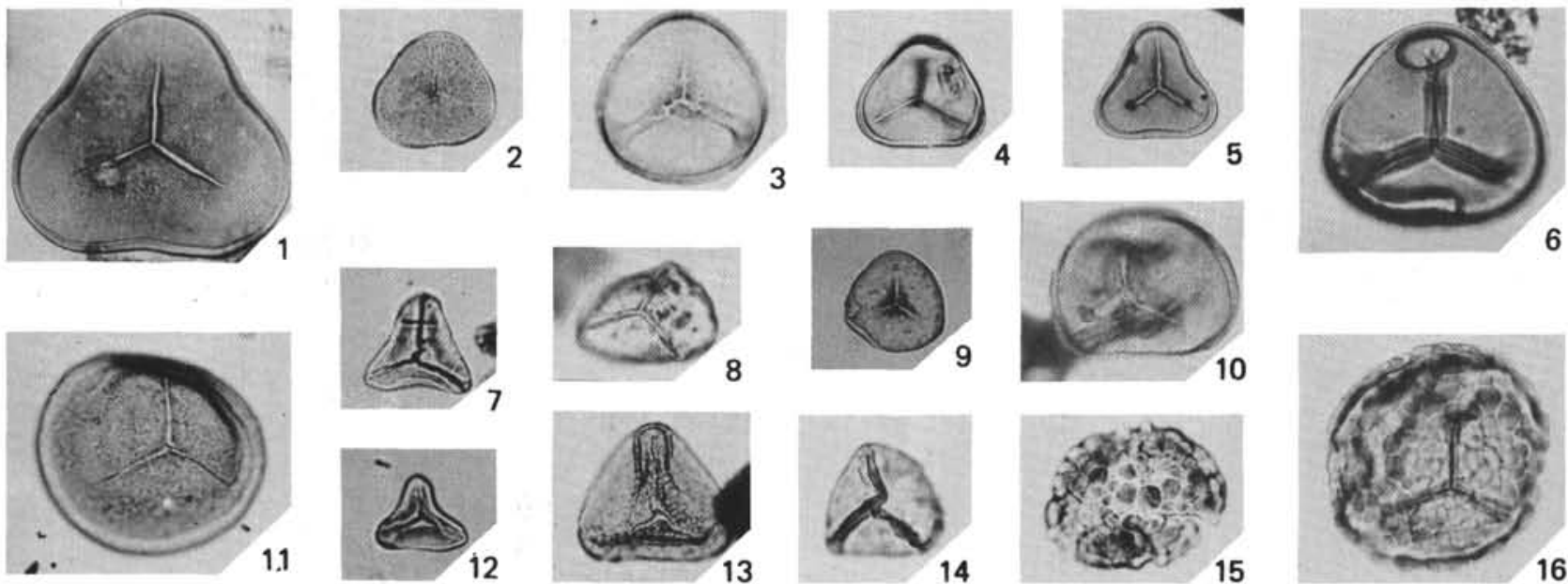
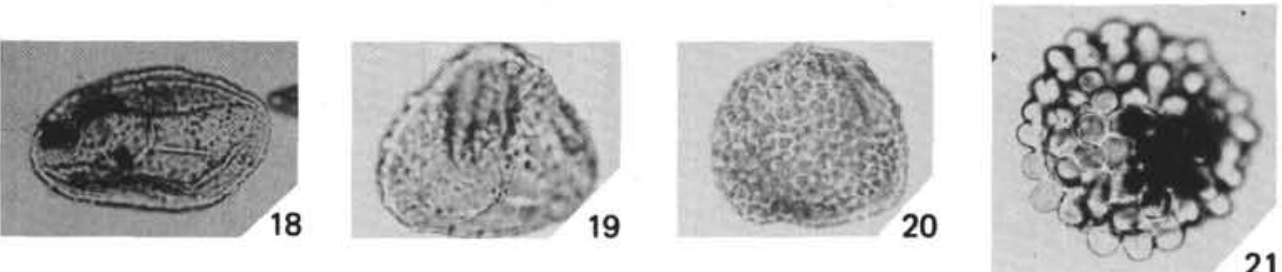

21
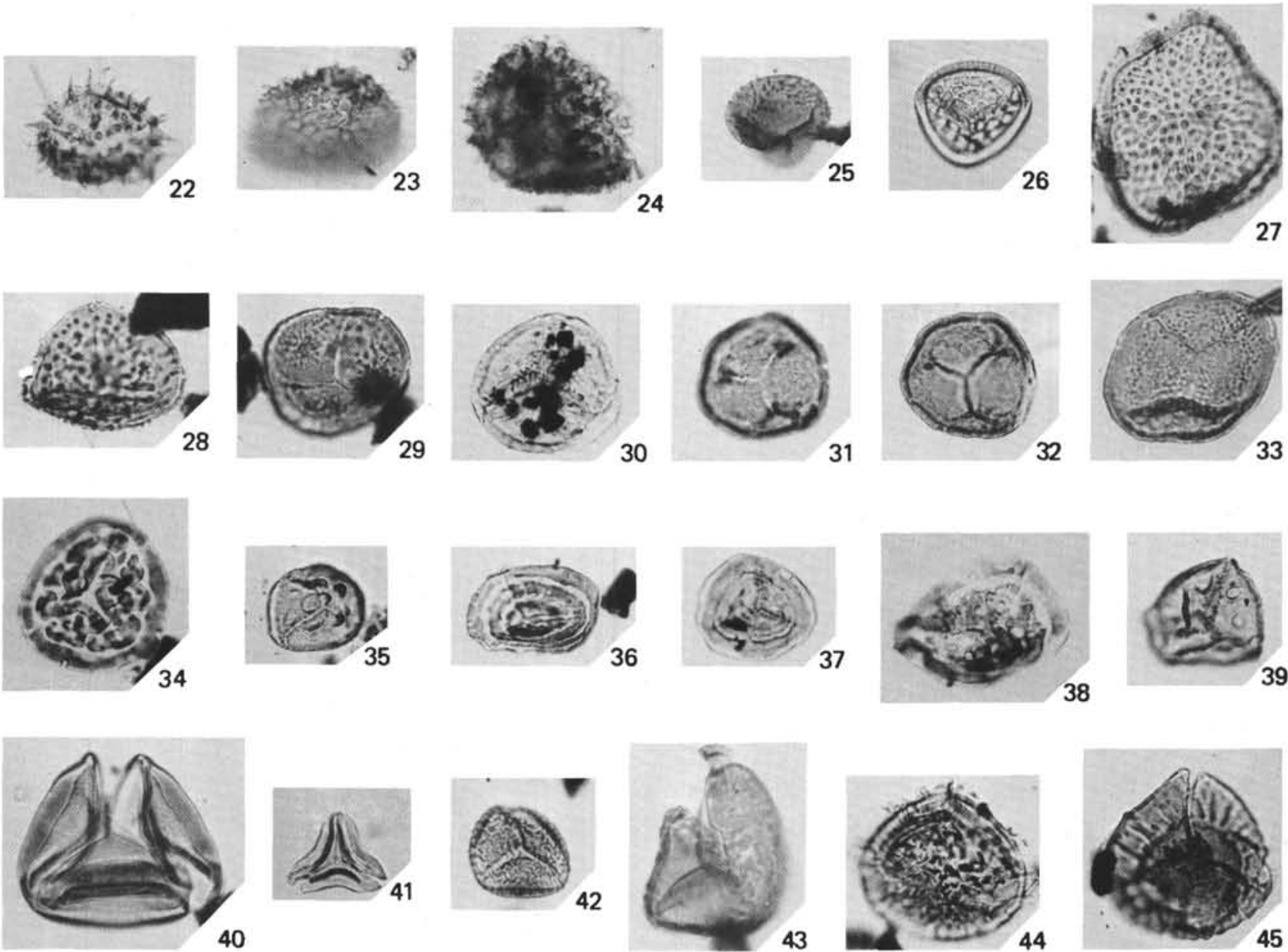


\section{PLATE 2}

All figures are magnified $\times 500$. Additional information in following order: Negative Number; Core Number; Sample Number; Coordinates on Zeiss photomicroscope mechanical stage.

Figure 1 Lycopodiumsporites facetus Dettmann, 1963, -22989; 13; 4978b; 112/3.

Figure 2 Lycopodiumsporites reticulumsporites (Rouse) Dettmann, 1963, -22990; 13; 4978b; 122.5/7.7.

Figure 3 Lycopodiumsporites austroclavatidites (Cookson) Potonié, 1956, -23028; 20; 4987b; 120.4/22.4.

Figure $4 \quad$ Lycopodiumsporites nodosus Dettmann, 1963, -23017; 20; 4987b; 113/20.8.

Figure $5 \quad$ Lycopodiumsporites crassatus Singh, 1971, -22988; 13; 4978a.1; 110.1/20.3.

Figure 6 Lycopodiumsporites crassimacerius Hedlund, 1966, -23110; 41; 5014b; 82/12.7.

Figure 7 Klukisporites foveolatus Pocock, 1964, -23111; 36; 5006b.1; 88.7/9.7.

Figure 8 Zlivisporites blanensis Palct, 1961, -22993; 13; 4978b; 79.3/14.

Figure 9 ?Tigrisporites $\mathrm{sp} .,-23052 ; 23 ; 4990 \mathrm{~b} ; 94 / 17.7$.

Figure $10 \quad$ Cicatricosisporites dorogensis Potonié and Gelletich emend Kedves, 1961, 23013; 13; 4978b; 116.7/19.

Figure $11 \quad$ Cicatricosisporites intersectus Rouse, 1962, -23012; 20; 4987b.1; 90/14.

Figure 12 Cicatricosisporites pseudotripartitus (Bolk) Dettmann, 1963, -22997; 18; 4984b.1; 121.2/11.6.

Figure 13 Cicatricosisporites claricanalis Phillips and Felix, 1971, -23061; 24; 4991b; $85 / 4.3$.

Figure $14 \quad$ Cicatricosisporites striosporites (Rouse) Kimyai, 1966, -23002; 19; 4986b; 92/10.5.

Figure $15 \quad$ Cicatricosisporites australiensis (Cookson) Pocock, 1956, -23109; 19; 4986b; $88.5 / 22$.

Figure 16 Cicatricosisporites venustus Deak, 1963, proximal view, -22999; 19; 4985b; 100.4/16.7.

Figure 17 Cicatricosisporites venustus Deak, 1963, distal view, -22998; 19; 4985b; 100.4/16.7.

Figure 18 Cicatricosisporites aralica (Bolkhovitina) Brenner, 1963, -23095; 39; 5008b; 90/19.8.

Figure 19 Cicatricosisporites exiguus Herngreen, 1971, -23086; 35; 5002b.1; 94.6/22.6.

Figure 20 Cicatricosisporites apiteretus Phillips and Felix, 1971, -23094; 39; 5008b; 87/15.

Figure $21 \quad$ Cicatricosisporites cuneiformis Pocock, 1965, -23080; 27; 4993b; 111.5/23.

Figure 22

Cicatricosisporites hughesi Dettman, 1963, -22986; 27; 4993b.1; 90/3.

Figure 23 Cicatricosisporites hallei Delcourt and Sprumont, 1955, -23108; 40; 5011b; 119/9.5.

Figure $24 \quad$ Cicatricosisporites carlylensis Pocock, 1962, proximal view, -23033; 21; 4988a; 81.4/18.7.

Figure $25 \quad$ Cicatricosisporites carlylensis Pocock, 1962, distal view, -23032; 21; 4988a; 81.4/18.7.

Figure $26 \quad$ Cicatricosisporites XIV, -23020; 17; 4983a; 117/15.7.

Figure $27 \quad$ Cicatricosisporites XIV, -23023; 13; 4978b; 88.5/12.6.

Figure 28 Appendicisporites degeneratus Thiergart, 1953, proximal view, -22984; 20; 4987b; 77.7/21.

Figure 29 Appendicisporites degeneratus Thiergart, 1953, distal view, -22983; 20; 4987b; $77.7 / 21$. 
PLATE 2
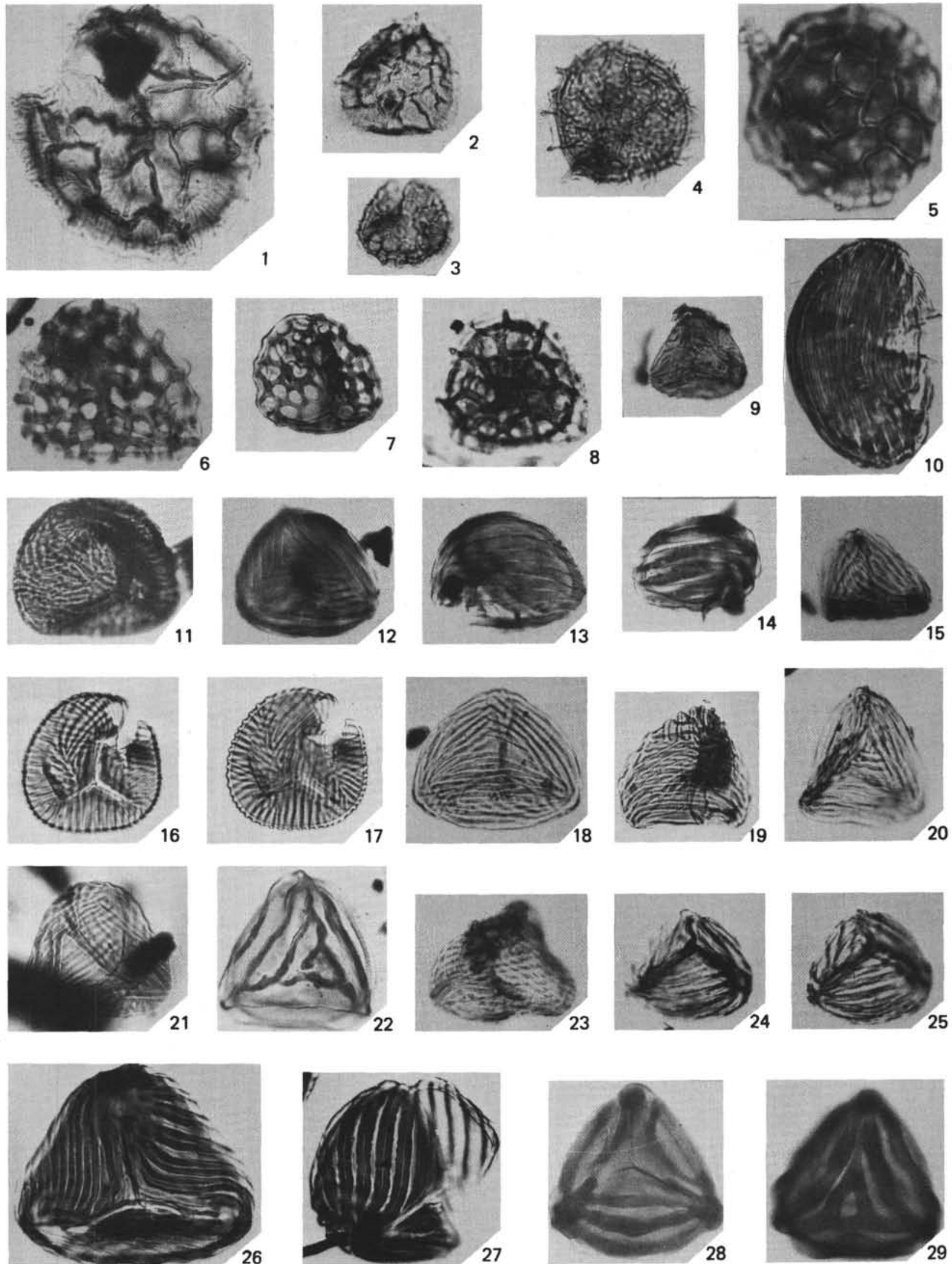


\section{PLATE 3}

All figures are magnified $\times 500$. Additional information in following order: Negative Number; Core Number; Sample Number; Coordinates on Zeiss photomicroscope mechanical stage.

Figure 1

Figure 2

Figure 3

Figure 4

Figure 5

Figure 6

Figure 7

Figure 8

Figure 9

Figure 10

Figure 11

Figure 12

Figure 13

Figure 14

Figure 15

Figure 16

Figure 17

Figure 18

Figure 19

Figure 20

Figure 21

Figure 22

Figure 23

Figure 24

Figure 25

Figure 26

Figure 27

Figure 28

Figure 29

Figure 30

Figure 31

Figure 32

Figure 33

Figure 34

Figure 35
Appendicisporites bilateralis Singh, 1971, -23015; 19; 4986b; 110.5/3.5.

Appendicisporites erdtmanii Pocock, 1964, -23069; 24; 4991b; 121/14.

Appendicisporites cristatus (Markova) Pocock, 1964, -23060; 24; 4991a; 93/16.

Appendicisporites jansonii Pocock, 1962, -23047; 21; 4988b; 103/22.3.

Appendicisporites crickmayii Pocock, 1964, -23088; 35; 5002b; 114/8.5.

Costatoperforosporites fistulosus Deak, 1962, -23068; 24; 4991b; 110/14.2.

Contignisporites cooksonii (Balme) Dettmann, 1963, -23093; 39; 5008b; 105/15.

Chomotriletes sp. $-23044 ; 19 ; 4986$ b; 89/3.

Rouseisporites simplex (Cookson and Dettmann) Dettmann, 1963, -23016; 19; 4986b; $120 / 3.4$.

Rouseisporites reticulatus Pocock, 1962, -23045; 19; 4985b; 115/10.4.

Kraeusslisporites majus (Cookson and Dettmann) Dettmann, 1963, -22994; 17; 4983b; 100.4/11.2.

Aequitriradites verrucosus (Cookson and Dettmann) Cookson and Dettmann, 1961, 22992; 13; 4978a; 99/3.5.

Aequitriradites spinulosus (Cookson and Dettmann) Cookson and Dettmann, 1961, $23010 ; 19 ; 4985$ b; 96/20.6.

Cyatheacidites tectifera Archangelsky and Gamerro, 1956, -23081; 28; 4995b; $96.3 / 22$.

Densoisporites perinatus Couper, 1958, -23123; 17; 4983b;101/18.

Polypodiisporites sp. 2, -23018; 20; 4987b; 106.5/21.

Polypodiisporites sp. 3, -23019; 20; 4987b; 93/21.

Punctatosporites sp., -23063; 24; 4991b; 76/15.8.

Laevigatosporites haardtii (Potonié and Venitz) Thomson and Pflug, 1953, -23057; $23 ; 4990$ b; $98 / 19.8$.

Laevigatosporites gracilis Wilson and Webster, 1946, -23056; 23; 4990b; 85/11.4.

Classopollis I, -22980; 48; 5024b; 82/20.7.

Classopollis IV, -22975; 47; 5023b; 103.7/7.8.

Classopollis V, -22978; 22; 4989b; 121.6/21.4.

Classopollis VI, -22979; 20; 4987b; 87.5/21.3.

Classopollis III, -23126; 27; 4993b.1; 100.5/18.8.

A raucariacites australis Cookson, 1947, -23100; 40; 5010b.1; 78/3.

Inaperturopollenites I+II, -23105; 43; 5016b; 122.5/8.6.

Inaperturopollenites limbatus Balme, 1957, -23120; 47; 5023b.1; 90.7/15.4.

Inaperturopollenites VI, -22971; 47; 5023b; 93/21.6.

Inaperturopollenites VII, -23125; 27; 4993b.1; 80/21.4.

Inaperturopollenites VIII, -23130; 20; 4987b; 92.4/21.4.

Tsugaepollenites trilobatus (Balme) Dettmann, 1963, -23119; 48; 5024b.1; 124/6.8.

Tsugaepollenites dampieri (Balme) Dettmann, 1963, -23127; 18; 4984b; 80/10.3.

Vitreisporites pallidus (Reissinger) Nilsson, 1958, -23128; 18; 4984b; 88/21.

Vitreisporites sp. Singh, 1971, -23050; 22; 4989b; 111.4/22.5. 
PLATE 3
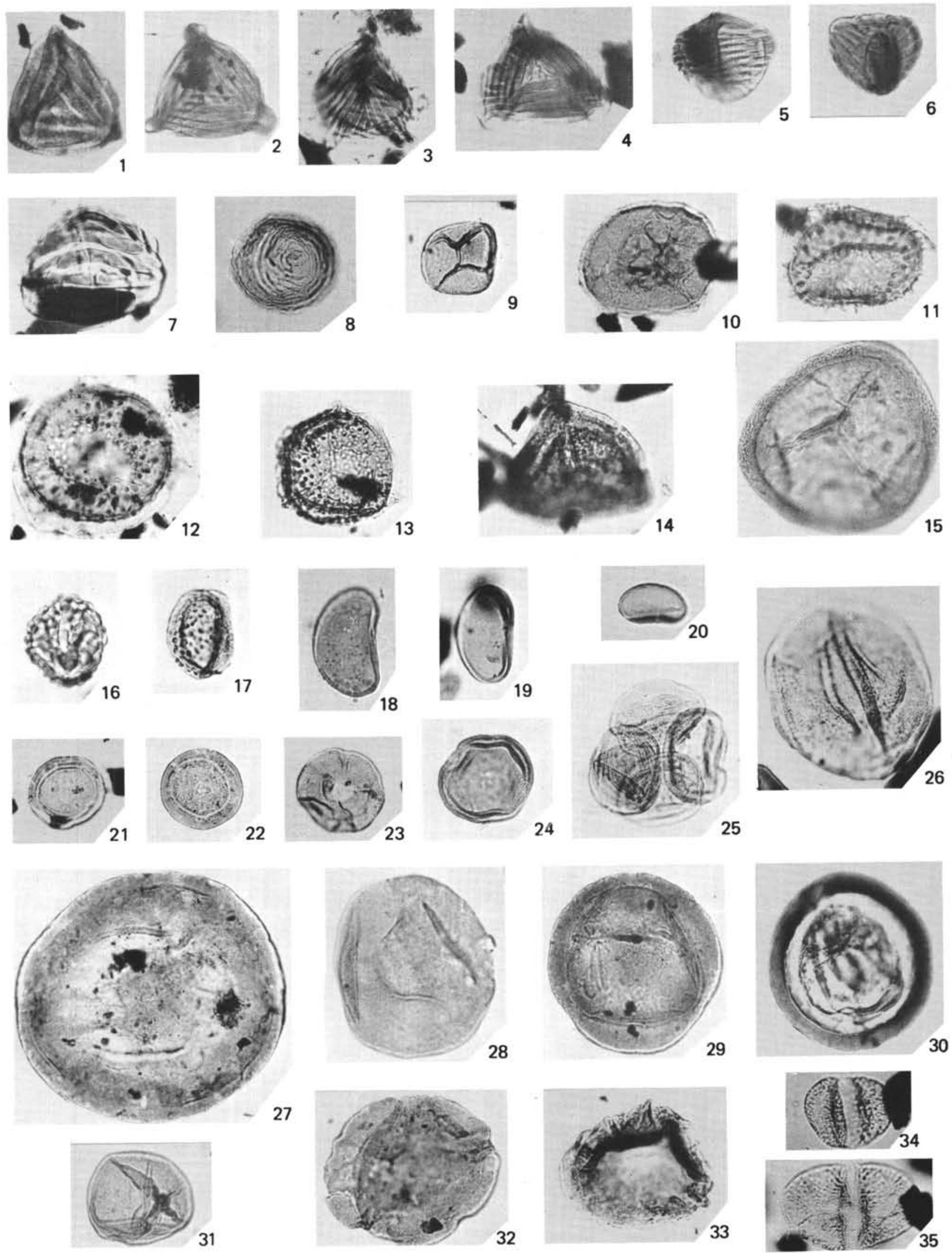
PLATE 4

Figures 1-18 are magnified $\times 500$; Figures $19-33 \times 1000$. Additional information in following order: Negative Number; Core Number; Sample Number; Coordinates on Zeiss photomicroscope mechanical stage.

Figure 1 Podocarpidites multesimus (Bolkhovitina) Pocock, 1962, -23116; 46; 5022b; 115/4.

Figure $2 \quad$ Podocarpidites marwickii Couper, 1953, -22981; 19; 4985b; 107.3/15.

Figure $3 \quad$ Podocarpidites ellipticus Cookson, 1947, -23129; 19; 4985b.1; 76/22.

Figure $4 \quad$ Microcachrydites antarcticus Cookson, 1947, -23078; 19; 4985b; 90.5/21.

Figure $5 \quad$ Phyllocladidites sp., -23011; 17; 4983b; 122.3/8.

Figure $6 \quad$ Alisporites bilateralis Rouse, 1959, -23115; 45; 5021b; 114/16.7.

Figure $7 \quad$ Alisporites similis (Balme) Dettmann, 1963, -23118; 40; 5010b.1; 109/20.3.

Figure $8 \quad$ Podosporites sp., -23042; 17; 4983b; 111.5/21.

Figure 9 Perinopollenites halonatus Phillips and Felix, 1971, -23053; 23; 4990b; 95.2/22.

Figure $10 \quad$ Schizosporis cooksonii Pocock, 1962, -23064; 24; 4991b; 115/14.3.

Figure $11 \quad$ Monosulcites perspinosus Couper, 1953, -23009; 19; 4985b; 89/11.6.

Figure 12 Cycadopites nitidus (Balme) de Jersey, 1964, -23098; 41; 5013b; 89.3/19.5.

Figure 13 Equisetosporites multistriatus Pocock, 1964, -23000; 19; 4986b; 96.5/10.5.

Figure 14 Equisetosporites fissuratus Phillips and Felix, 1971, -23065; 24; 4991b; 105/19.7.

Figure $15 \quad$ Equisetosporites virginiaensis (Brenner) Singh, 1971, -23087; 35; 5002b; 116/2.3

Figure 16 Equisetosporites rousei Pocock, 1964, -22996; 18; 4984b; 107/11.

Figure 17 Equisetosporites barghoornii Pocock, 1964, -22987; 39; 5008b.1; 85.3/16.

Figure $18 \quad$ Equisetosporites concinnus Singh, 1964, -23077; 19; 4985a; 112/12.

Figure 19 Steevesipollenites sp., -23151; 22; 4989b; 87.6/22.

Figure $20 \quad$ Liliacidites intermedius Couper, 1953, -23131; 24; 4991b; 101/14.9.

Figure $21 \quad$ Liliacidites crassatus Singh, 1971, -23143; 23; 49906; 120/22.2.

Figure 22 Liliacidites peroreticulatus (Brenner) Singh, 1971, -23139; 24; 4991b; 120.7/15.8.

Figure $23 \quad$ Liliacidites trichotomosulcatus Singh, 1971, -23135; 24; 4991b; 80.3/21.2.

Figure $24 \quad$ Liliacidites dividuus (Pierce) Brenner, 1963, -23133; 24; 4991b; 111/20.

Figure $25 \quad$ Liliacidites inaequalis Singh, 1971, -23148; 23; 4990b; 124/13.6.

Figure $26 \quad$ Clavatipollenites couperi Pocock, 1962, -23134; 24; 4991b; 107/23.

Figure 27 Clavatipollenites hughesi Couper, 1958, -23132; 24; 4991b; 92/20.3.

Figure 28 Clavatipollenites minutus Brenner, 1963, -23146; 23; 4990b; 91/21.

Figure $29 \quad$ Tricolpites parvus Stanley, 1965, -23137; 24; 4991b; 122/20.

Figure $30 \quad$ Tricolpites sp. $1-23147 ; 23 ; 4990$ b; 82/15.

Figure $31 \quad$ Tricolpites sp. 2 -23154; 24; 4991b; 81.3/14.5.

Figure $32 \quad$ Tricolpites sp. $3-23153 ; 22 ; 4989$ b; 106/20.9.

Figure $33 \quad$ Tricolpites sp. 4 -23150; 22; 4989b; 115/23.

Figure $34 \quad$ Porotrichotomosculcus sp. Phillips, 1971. 
PLATE 4
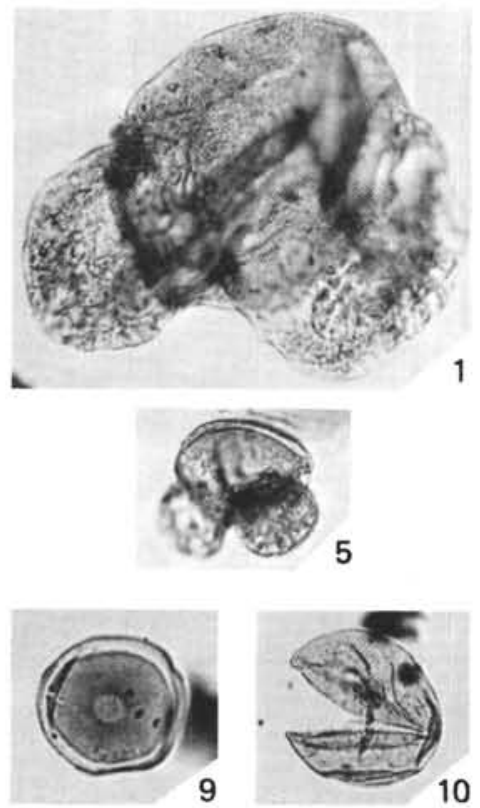

10
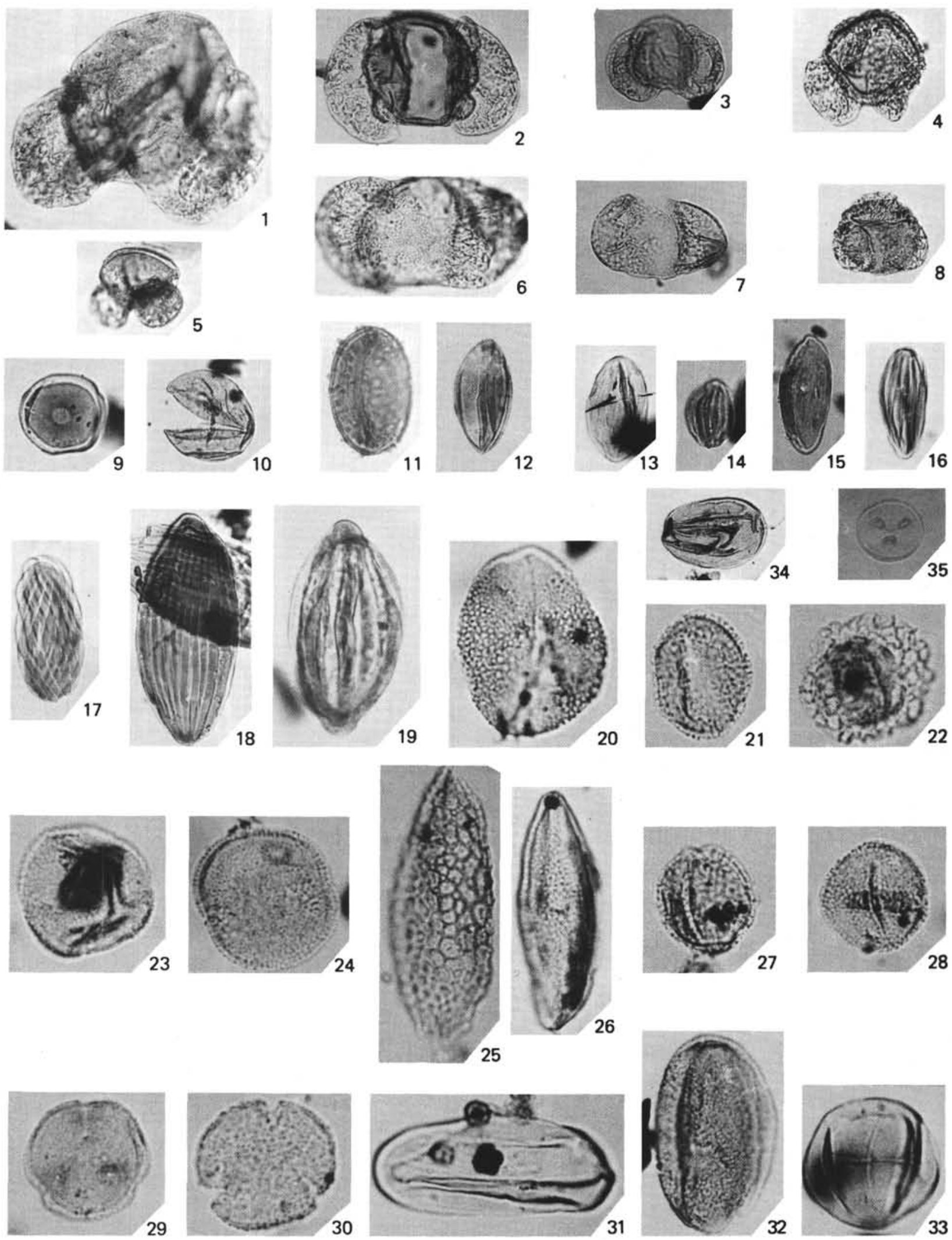
PLATE 5

All figures are magnified $\times 1000$; excepting figures 21-23 $\times 500$. Additional information in following order: Negative Number; Core Number; Sample Number; Coordinates on Zeiss photomicroscope mechanical stage.

Figure $1 \quad$ Tricolpites sp. 7, -23160; 19; 4986a; 77/5.

Figure $2 \quad$ Tricolpites sp. 9, -23168; 13; 4978b; 123/21.

Figure $3 \quad$ Tricolpites sp. 10, -23166; 17; 4983b.1; 99/14.

Figure $4 \quad$ Tricolpites sp. 6, -23156; 20; 4987b; 101.4/19.7.

Figure $5 \quad$ Tricolpites sp. 5, -23151; 22; 4989b; 101.4/19.7.

Figure $6 \quad$ Retitricolpites georgensis Brenner, 1963, -23155; 21; 4988b; 118/21.5.

Figure $7 \quad$ Retitricolpites maximus Singh, 1971, -23169; 13; 4978b; 79/17.

Figure $8 \quad$ Retitricolpites ellipticus Van Hoeken Klinkenberg, 1966, -23142; 24; $4991 \mathrm{~b} ; 98.5 / 13.7$.

Figure $9 \quad$ Psilatricolpites parvulus (Groat and Penny) Norris, 1967, -23141; 24; $4991 b ; 115.6 / 14.4$.

Figure $10 \quad$ Striopollenites sp., -23159; 19; 4985b; 111/16.

Figure $11 \quad$ Scollardia steevesi Srivastava, 1966, -23163; 18; 4984b; 76/20.5.

Figure $12 \quad$ Tetracolpate, $-23162 ; 19 ; 4985 b ; 106 / 7$.

Figure 13 Fraxinoipollenites venustus Singh, 1971, -23144; 23; 4990b; 120/22.2.

Figure $14 \quad$ Fraxinoipollenites rotundus Phillips and Felix, 1971, -23140; 24; 4991b; $80 / 20$.

Figure $15 \quad$ Polycolpate $-23158 ; 19 ; 4985 b ; 86 / 16.7$.

Figure $16 \quad$ Gemmatricolpites scabratus Van Hoeken-Klinkenberg, 1964, -23149; 23; 4990b; $123 / 14.3$.

Figure 17 Triporopollenites pseudocanalis Phillips and Felix, 1971, -23136; 24; $4991 b ; 76 / 20.3$.

Figure $18 \quad$ Nyassapollenites albertensis Singh, 1971, -23161; 19; 4986b; 76/6.8.

Figure $19 \quad$ Syncolpate, $-23164 ; 17 ; 4983 b ; 110 / 17.6$.

Figure $20 \quad$ Tricolporopollenites kruschii (Potonié) Thomson and Pflug, 1953, -23138; 24; $4991 \mathrm{~b} ; 118.5 / 17.6$.

Figure $21 \quad$ Incertae sedis A, $-23037 ; 17 ; 4983 \mathrm{~b} ; 118 / 6.5$.

Figure $22 \quad$ Incertae sedis A, -23035; 19; 4985b; 105/16.

Figure $23 \quad$ Incertae sedis A, -23039; 18; 4984b; 104/15.7.

Figure $24 \quad$ Cretacaeisporites mulleri Herngreen, 1973, -49157; 19; 4985b; 78/22.

Figure $25 \quad$ Triporate, $-23170 ; 13 ; 4978 b ; 124 / 12$.

Figure $26 \quad$ Proteacidites sp., $-23145 ; 23 ; 4990 b ; 119 / 21$.

Figure $27 \quad$ Proteacidites annularis Cookson, 1950, -23165; 17; 4983b; 101.4/16.7.

Figure $28 \quad$ Cupaneiidites sp., $-23167 ; 13 ; 4978$ a.1; 110/15.4 

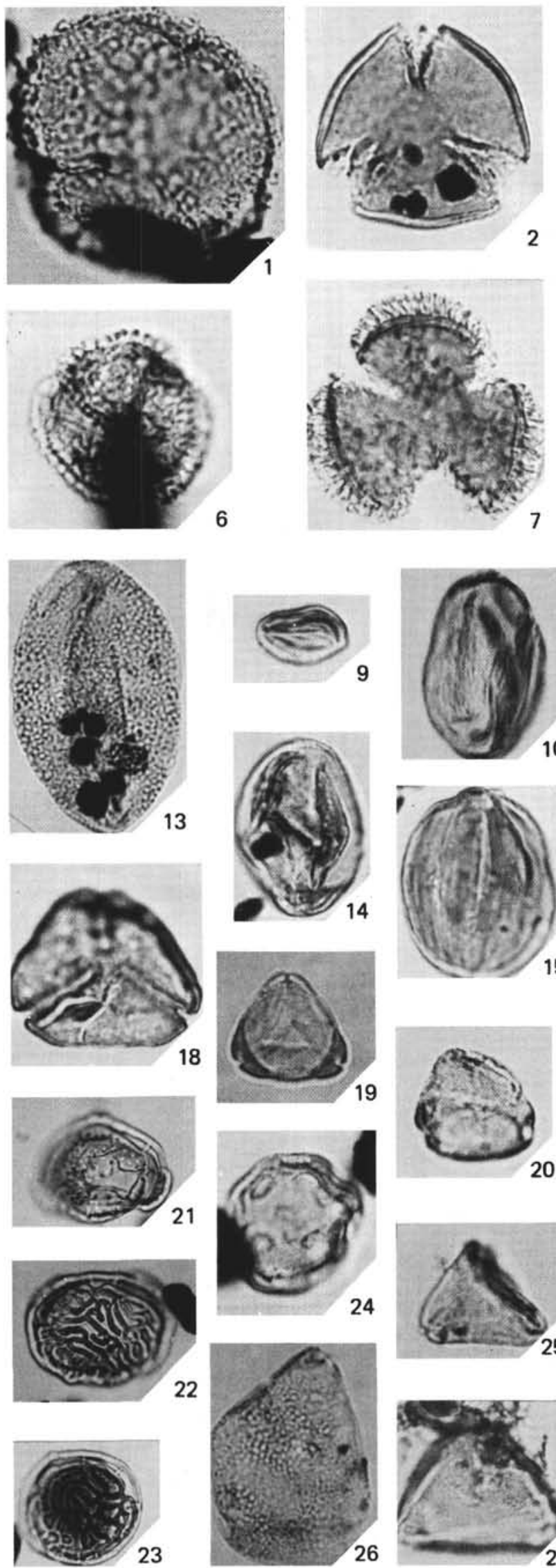

PLATE 5
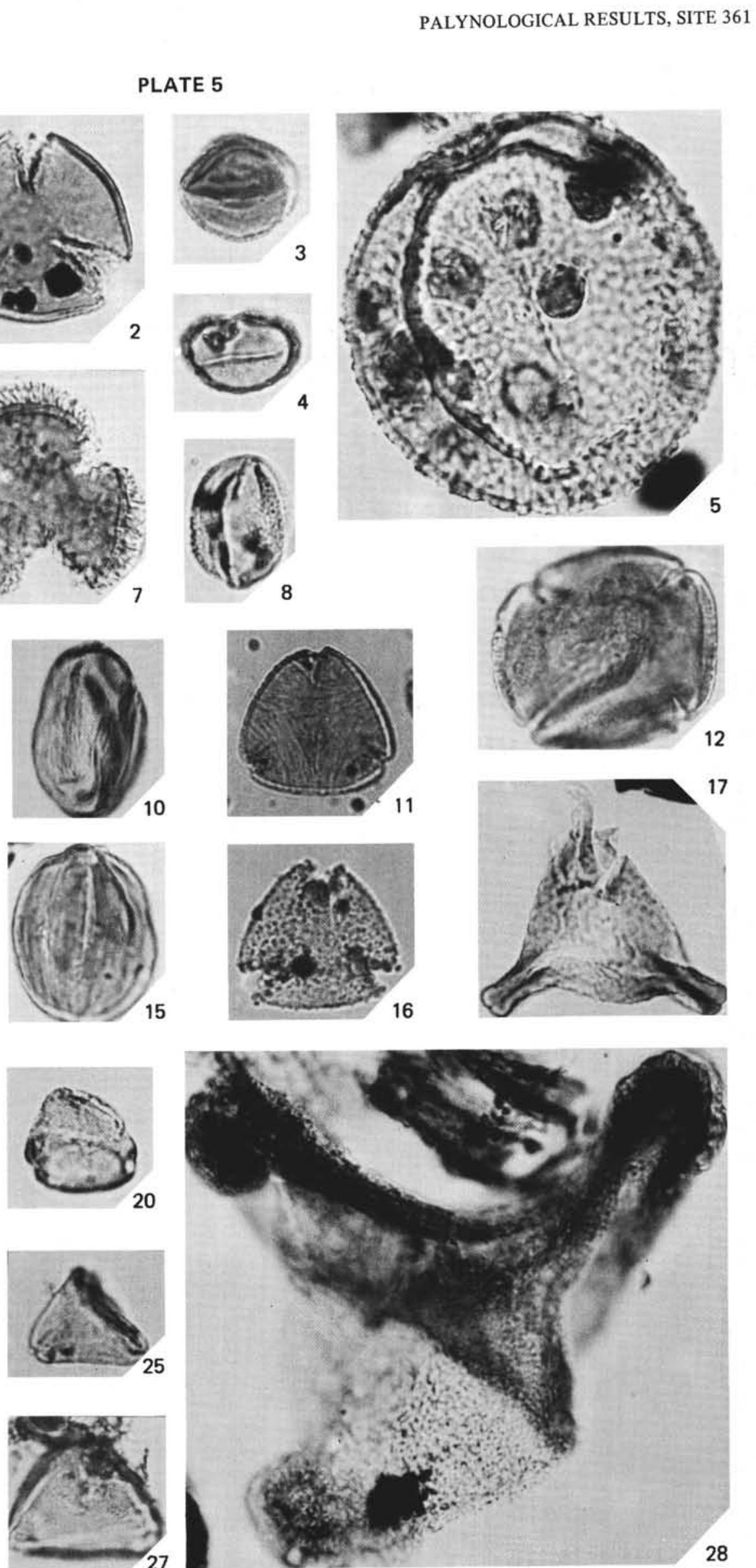